\title{
De novo characterization of the genetic polymorphism and transcript abundance of Toll-like receptors (TLRs) in tissues of swamp buffaloes (Bubalus bubalis) from Guangxi, China
}

\section{Wei Shi}

Guangxi University

Xuefang Mei

Guangxi University

Yangqun Kang

Guangxi University

Hany M. Elsheikha

University of Nottingham - Sutton Bonington Campus

Changhong $\mathrm{Hu}$

Guangxi University

\section{Yurui Wang}

Guangxi University

Kejing Lu

Guangxi University

Yaoyao Zhang

Guangxi University

\section{Zhaoan Sheng}

Guangxi University

\section{Dongying Wang}

Guangxi University

\section{Xingquan Zhu}

Chinese Academy of Agricultural Sciences

Weiyi Huang ( $\square$ wyhuang123@126.com )

Guangxi University

\section{Research article}

Keywords: Buffaloes, Toll-like receptor (TLR), Phylogenetics, Sequencing, Bioinformatics 
DOI: https://doi.org/10.21203/rs.3.rs-49550/v1

License: (c) (i) This work is licensed under a Creative Commons Attribution 4.0 International License. Read Full License 


\section{Abstract}

Background: Toll-like receptors (TLRs) are innate signaling receptors, which sense invading pathogens and play roles in induction of immune responses to counter infection. In this study, we for the first time, cloned, sequenced and characterized the coding sequences of TLRs 1-10 in the Chinese "swamp-type" Guangxi (GX) buffalo breed.

Results: Protein sequence analysis of the 10 TLRs showed that GX buffalo share significant sequence similarity with river buffalo ( 94.7 to $99.9 \%$ ) and other ruminants ( $89.6 \%$ to $99 \%$ ), but similarity with nonruminants was low (48\% to $91 \%$ ). Prediction of functional domains revealed the presence of Toll/IL-1 receptor domains and variable numbers of leucine-rich repeats (LRRs) in all TLRs of GX buffalo. Transmembrane domain and signal peptide were absent in TLRs 7, 9 and TLRs 1, 3, 9, 10, respectively.

When comparing GX buffalo and Nili-Ravi (NR) buffalo, the similarity of TIR domains ranged from $95.9 \%$ to $100 \%$, while variations were found in the number of LRR motifs between these two breeds. Phylogenetic analysis based on the coding DNA and protein sequences demonstrated that, GX buffalo and NR buffalo were closely related with respect to TLRs $1,2,4,5,7,8$ and 10. However, regarding TLRs 3,6 , and 9, GX buffalo clustered with genera Bos and Bison, but not NR buffalo. RT-qPCR analysis provided an overview of TLRs transcription in tissues of GX buffalo.

Conclusions: Our study obtained and characterized the full sequences of 10 TLR genes of GX buffaloes, and comparatively quantified the mRNA expression of these genes across various tissues of GX buffaloes. These findings lay the groundwork for discovering breed-specific differences in the occurrence and progression of infections in buffalo.

\section{Background}

Water buffaloes (Bubalus bubalis) provide considerable economic and societal benefits to millions of people in tropical countries. According to FAOSTAT (FAO: http://www.fao.org/faostat/), there are over 188 million buffaloes in the Asia-Pacific region, representing approximately $97 \%$ of the global buffalo population ( 195 million). With a population of 23 million, representing $\sim 12 \%$ of the buffalo population worldwide, China maintains the third largest breeding stock of buffaloes, only behind India ( 99 million) and Pakistan (26 million). In many rural areas of China, buffalo breeding is based on free-range farming and pasture grazing, and lacks necessary measures for disease prevention. This farming practice, besides being less sustainable, facilitates the animal-to-animal and accidental animal-to-human transmission of diseases to farmers and milk/meat consumers - leading to illnesses and even death (Wanapat and Chanthakhoun 2015; Klous et al. 2016); including foot-and-mouth disease (FMD), brucellosis, tuberculosis, schistosomiasis, fasciolosis and various arbo-viral diseases (Chen et al. 2014; Hassan et al. 2014; Angeles et al. 2015; Goraya et al. 2015; Minakshi et al. 2015; Nguyen et al. 2016; Odeniran and Ademola 2016; Miguel et al. 2017). Enhancing disease control in buffaloes will, therefore, benefit both agricultural economy and public health. 
In Asia, two main breeds of buffaloes exist: the swamp-buffaloes mainly found in China and southeast of Asia, and the river-buffaloes in India, Pakistan and neighboring regions (Shi et al. 2012). In recent decades, river-buffalo breeds, such as Murrah, Nili-Ravi (NR) and Mediterranean, were introduced by the Chinese government to crossbred with swamp buffaloes in Guangxi (GX) region in order to increase genetic diversity and improve the productivity of the native Chinese breed. Genetic differences exist between buffalo breeds (Kumar et al. 2007; Lei et al. 2007; Degrandi 2010; Yindee et al. 2010), and it is reasonable to hypothesize that genetic differences may also involve genetic polymorphisms in Toll-like receptors (TLRs), which can contribute to a varied immune response that may impact the buffalo breed's resistance or susceptibility to infection.

TLRs are the main family of pattern recognition receptors (PRRs), which recognize specific pathogenassociated molecular patterns (PAMPs), leading to the activation of antimicrobial host immune responses (Iwasaki and Medzhitov 2015). Increasingly, we are learning about the innate immune response and TLRs in animals and humans. There are $\sim 13$ known mammalian TLRs: TLRs 1-13 in murine animals (Hopkins and Sriskandan 2005), TLRs 1-10 (except TLR7) in rabbits (Chen et al. 2014), TLRs 1-10 in ruminants (Menzies and Ingham 2006; Chang et al. 2009; Raja et al. 2011), and TLRs 1-10 in humans (Rock et al. 1998; Werling and Coffey 2007). The full sequence of TLR genes has been discovered in humans, monkeys, mice, rats, rabbits, pigs, cattle, sheep, goats, horses and chicken (Rock et al. 1998; Yilmaz et al. 2005; Menzies and Ingham 2006; Shinkai et al. 2006; Werling and Coffey 2007; Turin and Riva 2008; Astakhova et al. 2009; Chang et al. 2009; Raja et al. 2011). Of note, TLRs 1-10 genes of Indian river type NR buffaloes have been cloned and sequenced (Dubey et al. 2013). However, TLR gene sequences of swamp-type buffaloes from GX region in China have not been evaluated.

Therefore, the aim of this study was to characterize, for the first time, the gene sequences of TLRs 1-10 of GX buffalo breed from GX region in China. We compared the genetic polymorphism and evolutionary relationship of TLRs of GX buffaloes to that of river buffaloes and other animal species. We also determined the relative mRNA expression levels of TLRs in blood leukocytes and different tissues of GX buffaloes. Our results on sequence characteristics and tissue abundance feature of swamp-type buffalo TLRs, may not only provide basic information for understanding the biological and functional similarities of these TLRs to homologous TLRs of other species, but also extend knowledge for future studies about the 'mammal TLR-pathogens' interactionship that benefits the researches for both veterinary and human medicine.

\section{Results}

\section{Confirming the identity of GX buffaloes}

The breed of GX buffaloes was confirmed as a swamp-type based on a combination of morphological and karyotyping analysis, and sequencing of the mitochondria D-loop region. The morphological features of GX buffaloes(swamp-type) were compared with Murrah and NR buffaloes (river-type) as shown in Additional file 1: Figure S1a. The native GX buffaloes had phenotypic characteristics typical to the 
swamp-type; with a flat forehead, wide oronasal area, large abdominal perimeter, long sides, and backwardly swinging horns. The growth direction of the horns is horizontal to the forehead. The spine of GX buffaloes suddenly becomes flat after the last thoracic region. The Murrah and NR buffaloes exhibited typical river-type features; with a well-developed udder, and taller and wider body, wider pelvis, upwardly-curled horns, deeply pigmented skin and hair, and spine that extends further into the hindquarters (Cockrill 1976; Zhang et al. 2000; Presicce 2017).

Karyotyping analysis showed that GX buffaloes possess $2 n=48$ chromosomes, of which 10 are metaand submetacentric, 36 acrocentric somatic chromosomes, and 2 acrocentric sex chromosomes (see Additional file 1: Figure S1b and c) - features that match the karyotype characteristic of swamp-type buffaloes (Degrandi 2010). The nucleotide sequence of the mitochondria D-loop region of GX buffaloes was amplified and sequenced (NCBI accession number: MG491488). NJ tree showed a separation between swamp-type buffaloes and river-type buffaloes, but GX buffaloes were more closely related to swamp-buffaloes, further supporting the breed identity of GX buffaloes as a swamp-type. The similarity of D-loop nucleotide sequences was highest between GX, and WZ and XY buffaloes (99.8\%). High similarity was also found with DC (99.7\%), XL (99.7\%) and FA (95.2\%). There was less similarity with river-type buffaloes: Mediterranean (93.3\%), Jaffarabadi (92.8\%), Surti (92.5\%), NR (91.5\%), and Murrah (89.3\%); similarity with the outgroup species of the genus Bison and genus Bos was $80.1-83.2 \%$ (see Additional file 1: Figure S1d). These results show that GX buffaloes are of a swamp-type, and are closely related to the Southwest Chinese cluster (DC, XL, WZ, XY)(Lei et al. 2007; Zhang et al. 2007).

\section{TLRs 1-10 sequence analysis}

We amplified and sequenced full-length TLRs 1-10 of GX buffaloes. The primer sequences, annealing temperature and expected PCR product length are shown in Table 1. The electrophoresis result shown in Fig. 1 indicates that all DNA fragments were amplified accorded to the expected size of each amplicon. The full-length sequences of TLRs 1-10 genes of GX buffaloes have been submitted to the NCBI GenBank, and the accession numbers are listed in Table 1. The coding sequences and deduced AA of these TLRs were compared with those of NR buffaloes, cattle, American bison, zebu, yak, wild yak, gayal, goat and sheep as "ingroups" (Table 3); then with other non-ruminant species including horse, pig, mouse, rat, rabbit, monkey and human as "outgroups" (see Additional file 2: Table S1). 
Table 1

Primer sets, PCR annealing temperature and amplicon size, and gene accession number for swamp buffalo TLRs 1-10 genes

\begin{tabular}{|c|c|c|c|c|}
\hline $\begin{array}{l}\text { TLR } \\
\text { gene }\end{array}$ & Primer sequence $\left(5^{\prime}-3^{\prime}\right)^{a}$ & $\begin{array}{l}\text { Amplicon } \\
\text { size (bp) }\end{array}$ & $\begin{array}{l}\text { Annealing } \\
\text { temperature }\left({ }^{\circ} \mathrm{C}\right)\end{array}$ & $\begin{array}{l}\text { Accession } \\
\text { number }^{b}\end{array}$ \\
\hline \multirow[t]{2}{*}{ TLR1 } & F: AAAAACTTATCCCTGGAAACA & 2261 & 50 & MG491497 \\
\hline & R: TATAAATCCCCGTGTTAATGT & & & \\
\hline \multirow[t]{2}{*}{ TLR2 } & F: ATGCCACGTGCTTTGTGGA & 2347 & 50 & MG491498 \\
\hline & R: TTATTGCAGCTCTCAAATTTAACCA & & & \\
\hline \multirow[t]{2}{*}{ TLR3 } & F: AAAACGAACTGGATTTGGACTAA & 2982 & 50 & MG491489 \\
\hline & R: TGGGTCAGATTATGTCAATTGGTA & & & \\
\hline \multirow[t]{2}{*}{ TLR4 } & F: TCCTAAATTCACTAACCCTGAGGT & 2986 & 52 & MG491490 \\
\hline & R:CTTAGCTCTAATTCAGTTTGATGGG & & & \\
\hline \multirow[t]{2}{*}{ TLR5 } & F: CCTCAAGGCTGTTGCTCAGT & 2651 & 52 & MG491491 \\
\hline & R: GCCTAGGAGATGGTGGTTACA & & & \\
\hline \multirow[t]{2}{*}{ TLR6 } & F: AGAAGCTGTCATTTTGTTTACAT & 2361 & 50 & MG491492 \\
\hline & R: AАСCTTTCACATCATCATTTTC & & & \\
\hline \multirow[t]{2}{*}{ TLR7 } & F: GGGTCCATCTCAGGCTGATC & 3393 & 55 & MG491493 \\
\hline & R: TCCACTTCCTTTGTCATGTATTG & & & \\
\hline \multirow[t]{2}{*}{ TLR8 } & F: GGTCAAAGCACTGCGAATTTCA & 3238 & 50 & MG491494 \\
\hline & R: TTGCTGTGCATTTTGACTATGC & & & \\
\hline \multirow[t]{2}{*}{ TLR9 } & F: CTAAGGGCTGCTCTCAGTGGTGGT & 3845 & 52 & MG491495 \\
\hline & R: ACTCTGTGCTATTCGGCTGTCGTG & & & \\
\hline \multirow[t]{2}{*}{ TLR10 } & $\begin{array}{l}\text { F: } \\
\text { AAAATTCATCTGAGGTGAACCAGTG }\end{array}$ & 2517 & 55 & MG491496 \\
\hline & R: TAGGTCCCAATCTCCCTAGGAGTG & & & \\
\hline \multicolumn{5}{|c|}{${ }^{a}$ Primer orientation: $F$, forward; $R$, reverse. } \\
\hline & ccession numbers for full-length se & & & studv. \\
\hline
\end{tabular}


Table 3

The similarity of the coding sequence (CDS), deduced amino acid (AA) sequence and Toll/IL-1 receptor (TIR) domain sequence of Toll-like receptor (TLR) genes between GX buffaloes and nine other ruminant species

\begin{tabular}{|c|c|c|c|c|c|}
\hline Name & Species & CDS identity (\%) & AA identity (\%) & TIR identity (\%) & GenBank No. \\
\hline \multirow[t]{9}{*}{ TLR 1} & river buffalo & 96.9 & 99 & 99.3 & HQ327989.1 \\
\hline & cattle & 96 & 97.8 & 100 & NM_001046504.1 \\
\hline & wild yak & 94.7 & 97.7 & 100 & XM_005897339.2 \\
\hline & zebu & 94.5 & 97.2 & 99.3 & XM_019962587.1 \\
\hline & yak & 97.1 & 97.2 & 100 & KJ101605.1 \\
\hline & gayal & 95.7 & 96.1 & 97.9 & KF905597.1 \\
\hline & bison & 94.9 & 97.8 & 100 & XM_010833592.1 \\
\hline & goat & 96.1 & 94.6 & 97.2 & HQ263209.1 \\
\hline & sheep & 95.3 & 96.6 & 99.3 & NM_001135060.2 \\
\hline \multirow[t]{9}{*}{ TLR 2} & river buffalo & 96.6 & 98.9 & 98.6 & HM756162.1 \\
\hline & cattle & 92.7 & 97.1 & 97.9 & NM_174197.2 \\
\hline & wild yak & 90.4 & 95.7 & 92.5 & XM_014480820.1 \\
\hline & zebu & 91.5 & 96.8 & 97.2 & XM_019978018.1 \\
\hline & yak & 96.8 & 96.9 & 97.9 & KF977429.1 \\
\hline & gayal & 96.3 & 96.3 & 96.6 & KF905578.1 \\
\hline & bison & 97.5 & 96.7 & 96.6 & EU580539.1 \\
\hline & goat & 97.9 & 96.9 & 95.2 & NM_001285603.1 \\
\hline & sheep & 95.2 & 92.3 & 91.7 & NM_001048231.1 \\
\hline \multirow[t]{8}{*}{ TLR 3} & river buffalo & 96.7 & 95.8 & 98.6 & HQ343417.1 \\
\hline & cattle & 96.9 & 97 & 97.9 & NM_001008664.1 \\
\hline & wild yak & 95.2 & 97.8 & 99.3 & XM_005899004.2 \\
\hline & zebu & 95.1 & 97.6 & 99.3 & XM_019953354.1 \\
\hline & yak & 98.2 & 97.8 & 99.3 & KF990165.1 \\
\hline & gayal & 93.5 & 97.9 & 98.7 & KF905599.1 \\
\hline & bison & 95.2 & 97.9 & 99.3 & XM_010835803.1 \\
\hline & goat & 93.9 & 89.6 & 94.9 & HQ263210.1 \\
\hline
\end{tabular}




\begin{tabular}{|c|c|c|c|c|c|}
\hline Name & Species & CDS identity (\%) & AA identity (\%) & TIR identity (\%) & GenBank No. \\
\hline & sheep & 96.8 & 96.2 & 99.3 & NM_001135928.1 \\
\hline \multirow[t]{9}{*}{ TLR 4} & river buffalo & 93 & 97 & 97.9 & HQ343416.1 \\
\hline & cattle & 91.8 & 96.7 & 97.9 & NM_174198.6 \\
\hline & wild yak & 91.6 & 96.3 & 97.9 & XM_005891938.1 \\
\hline & zebu & 95 & 96.2 & 98.6 & KX138607.1 \\
\hline & yak & 97.4 & 96.3 & 97.9 & KF977430.1 \\
\hline & gayal & 85.4 & 96.4 & 98.6 & HQ327993.1 \\
\hline & bison & 86.8 & 96.6 & 98.6 & AH015104.2 \\
\hline & goat & 93.6 & 93.2 & 97.3 & NM_001285574.1 \\
\hline & sheep & 95.9 & 93.7 & 97.3 & NM_001135930.1 \\
\hline \multirow[t]{9}{*}{ TLR 5} & river buffalo & 98.2 & 98.7 & 100 & NM_001290918.1 \\
\hline & cattle & 94.9 & 94.9 & 95.2 & NM_001040501.1 \\
\hline & wild yak & 94.8 & 97.9 & 97.9 & XM_005903731.1 \\
\hline & zebu & 97.9 & 97.6 & 97.3 & GQ866979.1 \\
\hline & yak & 95.7 & 97.3 & 95.9 & GU647093.1 \\
\hline & gayal & 92.5 & 92.4 & 91.4 & HQ392514.1 \\
\hline & bison & 95.2 & 97.7 & 97.9 & JN615236.1 \\
\hline & goat & 96.3 & 92.4 & 95.7 & NM_001285699.1 \\
\hline & sheep & 96.8 & 95.1 & 97.9 & NM_001135926.1 \\
\hline \multirow[t]{9}{*}{ TLR 6} & river buffalo & 96.6 & 94.7 & 96.1 & HQ327992.1 \\
\hline & cattle & 97.7 & 96.9 & 96.1 & NM_001001159.1 \\
\hline & wild yak & 98.3 & 97.8 & 99.2 & XM_005897340.1 \\
\hline & zebu & 98.1 & 97.7 & 98.4 & XM_019962585.1 \\
\hline & yak & 98.4 & 98 & 99.2 & KM359137.1 \\
\hline & gayal & 98.7 & 98 & N/A & KC161554.1 \\
\hline & bison & 98.4 & 98.1 & 98.4 & XM_010833587.1 \\
\hline & goat & 95.1 & 91 & 90.7 & NM_001285540.1 \\
\hline & sheep & 96.6 & 94.3 & 99.2 & NM_001135927.1 \\
\hline
\end{tabular}




\begin{tabular}{|c|c|c|c|c|c|}
\hline Name & Species & CDS identity (\%) & AA identity (\%) & TIR identity (\%) & GenBank No. \\
\hline \multirow[t]{9}{*}{ TLR 7} & river buffalo & 98.5 & 99.9 & 100 & GU903503.1 \\
\hline & cattle & 98.5 & 99 & 100 & NM_001033761.1 \\
\hline & wild yak & 97.4 & 99 & 100 & XM_005891026.2 \\
\hline & zebu & 97.4 & 99 & 98 & XM_019956405.1 \\
\hline & yak & 94.8 & 97.4 & 100 & GQ438259.1 \\
\hline & gayal & 95.3 & 98.2 & $\mathrm{~N} / \mathrm{A}$ & KF905583.1 \\
\hline & bison & 91.9 & 97.1 & 100 & XM_010830634.1 \\
\hline & goat & 94.7 & 92.4 & 86.1 & NM_001285543.1 \\
\hline & sheep & 96.9 & 98.5 & 100 & NM_001135059.1 \\
\hline \multirow[t]{9}{*}{ TLR 8} & river buffalo & 99.7 & 99.4 & 99.3 & NM_001290928.1 \\
\hline & cattle & 97.2 & 96.6 & 99.3 & NM_001033937.1 \\
\hline & wild yak & 97.1 & 98.1 & 100 & XM_005891027.2 \\
\hline & zebu & 94.3 & 98 & 100 & XM_019956418.1 \\
\hline & yak & 98.4 & 97.9 & 100 & KM359140.1 \\
\hline & gayal & 98.1 & 97.3 & 98 & KF905575.1 \\
\hline & bison & 96.3 & 98.2 & 100 & XM_010830635.1 \\
\hline & goat & 99.3 & 98.8 & 99.3 & NM_001285757.1 \\
\hline & sheep & 97.7 & 97.6 & 99.3 & NM_001135929.1 \\
\hline \multirow[t]{9}{*}{ TLR 9} & river buffalo & 96 & 97.2 & 100 & HQ242779.1 \\
\hline & cattle & 94.7 & 98.2 & 98.6 & NM_183081.1 \\
\hline & wild yak & 97.1 & 96.5 & 99.2 & XM_014478899.1 \\
\hline & zebu & 96.8 & 98.3 & 99.3 & KX138608.1 \\
\hline & yak & 97.8 & 97.9 & 98 & KM359141.1 \\
\hline & gayal & 95.9 & 96.3 & 98.6 & KF905585.1 \\
\hline & bison & 83.5 & 98.4 & 99.3 & XM_010851751.1 \\
\hline & goat & 95.7 & 95.2 & 98 & EU747825.1 \\
\hline & sheep & 94.2 & 95.3 & 98 & NM_001011555.1 \\
\hline TLR 10 & river buffalo & 94.3 & 95.2 & 95.9 & HQ327991.1 \\
\hline
\end{tabular}




\begin{tabular}{|clllll|}
\hline Name & Species & CDS identity (\%) & AA identity (\%) & TIR identity (\%) & GenBank No. \\
\hline cattle & 94.8 & 96.9 & 90.4 & NM_001076918.2 \\
\hline wild yak & 94.9 & 96.9 & 98.6 & XM_005897338.1 \\
\hline zebu & 95.8 & 96.7 & 97.9 & EU006659.1 \\
\hline yak & 95.7 & 96.1 & 98.6 & KF776527.1 \\
\hline gayal & 96 & 96.7 & 98.6 & KF905606.1 \\
\hline bison & 94.7 & 97 & 98.6 & XM_010833593.1 \\
\hline goat & 93.1 & 87.8 & 90.4 & NM_001285541.1 \\
sheep & 96.6 & 95.4 & 95.9 & NM_001135925.1 \\
\hline
\end{tabular}

The coding sequence, deduced AA sequence and the predicted TIR domain of most TLRs were conserved across the nine ruminant species (especially river-type buffaloes), but were divergent from non-ruminant mammals. There was a high degree of similarity $(>90 \%)$ with coding sequences of ruminant (river-type buffalo, cattle, sheep and goat) TLRs, whereas a $67-89 \%$ similarity was detected to the sequences of horse, pig, mouse, rat, rabbit, monkey, and human. At the AA level, the similarity of TLRs between GX buffaloes and river-type buffaloes was $94.7-99.9 \%$, whereas a $89.6-99 \%$ similarity with ruminant species and $48-91 \%$ similarity to non-ruminant species were detected. TLR7 of GX buffaloes showed the highest amino acid homology to that of river-type buffaloes (99.9\%). Although the coding sequences of TLR 6 of GX buffaloes had $96.6 \%$ identity with river-type buffaloes, TLR6 AA sequence of GX buffaloes was more similar to yak, gayal or bison ( 98\%), cattle (96.9\%), wild yak (97.8\%) and zebu (97.7\%); than to NR buffaloes (94.7\%). AA sequences of GX buffalo TLR9 and TLR10 were more similar to domestic cattle, zebu or bison ( 98\% and 97\%, respectively) compared to NR buffaloes (97.2\% and $95.2 \%$, respectively). The lower AA sequence similarities in TLRs 6, 9 and 10 between the swamp-type and river-type buffaloes point out to breed-specific differences in the biological function of these TLRs. Compared with nonruminant mammals, the similarities between TLRs of GX buffaloes and ruminant species were high, suggesting that TLRs might have evolutionary conserved functions across ruminants.

\section{Prediction of functional domains}

A simple modular architecture tool (SMART) was used to predict the functional domains of TLRs, including the signal peptide (SP), transmembrane(TM), TIR and LRR domains (Fig. 2). Similar to river-type buffaloes, TLRs 1-10 of swamp-type buffaloes possessed LRR and TIR domains, however the TM domains varied across different TLRs. No TM domain was found in TLR7 nor TLR9, of both GX buffaloes and NR buffaloes. This was consistent with an earlier report on river-type buffaloes (Dubey et al. 2013). Surprisingly, only one TM domain was found at the C-terminus of TLR5 and TLR6in GX swamp-type buffaloes, rather than the two TM domains found in the homologous TLRs of river-type buffaloes, which was inconsistent with a previous study(Dubey et al. 2013). TMHMM was employed to confirm the finding, 
and the result completely matched the SMART prediction. Instead of the N-terminus TM domain, a SP domain was found. This feature suggests that TLR5 and TLR6 of swamp-type buffaloes are secretory proteins.

The cytoplasmic TIR domain plays a central role in cell signal transduction cascade downstream of TLRs through adaptors, such as myeloid differentiation factor 88 (MyD88), TIR domain-containing adaptor inducing interferon (TRIF), TRIF-related adaptor molecule(TRAM) and TIR domain containing adaptor protein(TIRAP)/Mal(Yamamoto et al. 2004; Kawai and Akira 2010). Sequences of the intracellular signaltransducing TIR domains were subjected to multiple alignments across species. TIR domains were found to be conserved across ruminant TLRs, with a similarity that ranged from $86.1-100 \%$. TIR identity of TLR5, 7 and 9 between swamp-type and river-type buffaloes was 100\%, whereas that of TLR6 $(96.1 \%)$ and TLR10 (95.9\%) was relatively lower, when compared to other TLRs. For TLR1 and TLR8, the TIR similarities were up to $100 \%$ between GX buffaloes and Bos species, but were slightly lower (99.3\%)between GX buffaloes and NR buffaloes. Although GX buffaloes are more closely related to NR buffaloes than other ruminant species in the phylogenetic tree, the result indicated that the TIR domain of TLR6 was more conserved among GX buffaloes, wild yak, yak and sheep (99.2\%) compared to river-type buffaloes (96.1\%). There was also a $98.6 \%$ similarity in TIR10 between GX buffaloes and wild yak, yak, gayal or bison; but only a $95.9 \%$ similarity between GX buffaloes and NR buffaloes, and a $90.4 \%$ similarity between $\mathrm{GX}$ buffaloes and domestic cattle. These results indicate that coding sequences, deduced AA sequence and predicted TIR domains of most TLRs, were relatively more conserved among ruminants - but were divergent from human, mouse and chicken, as expected.

The highly-conserved LRR regions, located extracellularly, are associated with pathogen ligand binding (Kobe and Kajava 2001). To predict the module number of LRR motifs present in TLRs of GX buffaloes, the LRR finder web application based on a large LRR database (tLRR $\mathrm{db}$ ) was used (Matsushima et al. 2007; Offord et al. 2010). The number of LRRs in TLRs 1-10 across various mammal species was compared, and the results are presented in Table 4. In swamp-type buffaloes, the number of LRR modules varied from 18 (TLR10) to 26 (TLRs 7, 8 and 9), which was similar to the range reported in river-type buffaloes(Dubey et al. 2013). Most TLRs of swamp-type buffaloes shared an equal number of LRR modules with river-type, except for TLRs 1, 6 and 10. TLRs 7, 8 and 9 were found to have an equal number of LRRs among sequences analyzed from all ruminant species (26 LRRs), except gayal TLR7 (25 LRRs), bison TLR7 (uncertain) and cattle TLR8 (25 LRRs), suggesting their conserved nature among ruminant species. GX buffalo TLRs 1, 2, 3, 4, and 5 had an equal or similar (+/- one LRR) number of LRR modules to cattle, wild yak, zebu, yak, bison and sheep. TLR6 and TLR10 of swamp-type buffaloes and zebu had equal number of LRRs, whereas the number of LRRs in these two TLRs in swamp-type buffaloes was similar to other ruminant species. The mammalian LRR motif has been shown to play a role in protein-protein interaction(Kobe and Deisenhofer 1994). Duplication or deletion of individual LRR motifs may alter the protein's stability and affinity, and subsequently change the function of ligand recognition in some TLRs (Björklund et al. 2006; Peter et al. 2009; Vieux and Barrick 2011). Our result indicates a possible evolutionary divergence in most of the TLR1 subfamily (TLRs 1, 6 and 10) between 
swamp-type and river-type buffaloes, which might lead to differential recognition of TLR ligands, despite their highly homologous sequences.

Table 4

Number of Leucine-rich repeats (LRRs) identified based on the amino acid sequences of the 10 Toll-like receptor (TLR) genes in GX buffaloes and nine other ruminant species. Accession numbers of TLRs used for the prediction analysis are provided in Table 3

\begin{tabular}{|lllllllllll|}
\hline TLRs & $\begin{array}{l}\text { GX buffalo } \\
\text { (this study) }\end{array}$ & $\begin{array}{l}\text { NR } \\
\text { buffalo }\end{array}$ & Cattle & $\begin{array}{l}\text { Wild } \\
\text { yak }\end{array}$ & Zebu & Yak & Gayal & Bison & Goat & Sheep \\
\hline TLR1 & 19 & 18 & 19 & 19 & 19 & $\begin{array}{l}20 \\
\text { a }\end{array}$ & 17 & 20 & 19 & 19 \\
\hline TLR2 & 20 & 20 & 20 & 20 & 19 & 20 & 17 & 19 & 20 & 20 \\
\hline TLR3 & 24 & 24 & 24 & 24 & 24 & 24 & $17^{a}$ & 24 & 21 & 24 \\
\hline TLR4 & 22 & 22 & 22 & 22 & 21 & 21 & 22 & 22 & 22 & 22 \\
\hline TLR5 & 23 & 23 & 23 & 23 & 23 & 23 & 22 & 23 & 23 & 23 \\
\hline TLR6 & 19 & 20 & 20 & 20 & 19 & 20 & $12^{\text {a }}$ & 20 & 18 & 20 \\
\hline TLR7 & 26 & 26 & 26 & 26 & 26 & 26 & 25 & $14^{\text {a }}$ & 26 & 26 \\
\hline TLR8 & 26 & 26 & 25 & 26 & 26 & 26 & 26 & $266^{\text {a }}$ & 26 & 26 \\
\hline TLR9 & 26 & 26 & 26 & 26 & 26 & 26 & 26 & 26 & 26 & 26 \\
\hline TLR10 & 18 & 20 & 20 & 20 & 18 & 19 & 20 & 20 & 20 & 20 \\
\hline a denotes partial AA sequence. & & & & & & & & \\
\hline
\end{tabular}

SMART analysis showed that TLRs 2, 4, 5, 6, 7 and 8 of GX buffaloes contained a SP domain at their Nterminus, suggesting their role as secretory proteins, however, TLRs 1, 3, 9 and 10 were non-secretory. As for NR buffaloes, the SP domain was absent in TLRs 1, 3, 5, 6 and 10, but present in the rest of the TLRs. The absence of a SP domain in TLRs 1, 6 and 10 had been noted in other Indian river-type buffalo breeds (Banerjee et al. 2012). It is clear that the occurrence of SP domains in TLRs can vary between breeds during their evolutionary divergence. The result of the SMART prediction concurred with the result of the SignalP4.1 prediction(Nielsen 2017)(see Additional file 3: Figure S2). SignalP-4.1 also provided the cleavage sites of GX buffalo TLRs 2, 4, 5, 6, 7 and 8, which were located at 20-21 aa, 25-26 aa, 20-21 aa, 22-23 aa, 26-27 aa and 18-19 aa, respectively. SPs are critical for protein translocation and export(von Heijne 1990). A TLR carrying a SP domain determines the N-terminus of the mature TM protein on either the non-cytoplasmic side or cytoplasmic side (Käll et al. 2004). Combined with the results from the TM prediction, it is possible to suggest that TLRs 2, 4, 5, and 6 of GX buffaloes are located on the plasma membrane. The only exception was the presence of a SP domain in TLR3 of both 
buffalo types based on our SignalP-4.1 analysis, but this was not revealed by SMART prediction. This result might be attributed to differences in the algorithms used in the two approaches; however, the presence or absence of a signal peptide does not completely control the localization of a protein.

The LRRCT and LRRNT domains (cysteine flanking cap regions of LRR at the $\mathrm{C}$ - and N-terminus, respectively) were also predicted in the GX buffalo TLRs 1-10. LRRCT was found to be present in all GX swamp-type buffalo TLRs except TLR9, as was predicted in river-type buffalo TLRs; whereas LRRNT was absent in all TLRs, except TLR3 and TLR7, as expected (Dubey et al. 2013). The high similarity in the structural features of LRRCT and LRRNT, suggest a similar function in receptor activation, or ligandbinding events, among TLRs 1-10 in these two buffalo breeds.

\section{Prediction of protein structure}

Analysis of the predicted GX buffalo TLRs 1-10 amino acid sequences indicated that the putative AAs encoded by ORFs were 727 aa, 877 aa, 904 aa, 891 aa, 871 aa, 736 aa, 1050 aa, 1033 aa, 1081 aa and 812 aa, respectively. The results of the prediction of the physical and chemical properties of these proteins can be found in Additional file 4: Table S2. The GX buffalo TLR 2 and 9 were positively charged, according to the predicted charge characteristics and theoretical pl; whereas the other TLRs were negatively charged. A comparative analysis of the AA composition of the putative product encoded by the GX buffalo TLRs 1-10 genes, showed that Leu had the highest frequency (14.4\%-18.2\%), followed by Ser (8\%-10.5\%); both are very similar to the content of Leu and Ser in NR buffalo TLRs 1-10 (14.4\%-18.7\% and $8 \%-10.5 \%$, respectively) (see Additional file 5: Table S3). Analysis of the hydrophobicity of TLR proteins, in this study, was based on the machine-calculating grand average of hydropathicity (GRAVY) values. The GRAVY values of GX buffalo TLRs $1-10$ were $-0.046,-0.203,-0.125,0.031,0.026,-0.057$, $-0.13,-0.135,-0.035$ and -0.053 , respectively. These values revealed that TLR4 and TLR5 were hydrophobic proteins, and the rest of TLRs were all hydrophilic proteins. The hydrophobicity of TLRs 110 in NR buffaloes showed consistent results with GX buffaloes (the comparative results are shown in

\section{Additional file 6: Figure S3).}

Combined analysis using the ProtComp, TargetP and PredictProtein programs, indicated that TLRs 1, 2, 6 , 10 are more likely to be located in both the cytoplasm and membrane, whereas TLRs 4, 5, 6 are located on the plasma membrane (extracellular), and TLRs 3, 7, 8, 9 are in the cytoplasm or intracellular organelles. Our analysis also showed a high possibility for the existence of a secretory pathway characterized by containing a SP in TLR3 and TLR4. Prediction of transmembrane helices in TLR proteins was performed by TMHMM 2.0 (see Additional file 7: Figure S4); and showed that the classical type I TM domain was present in TLRs 1, 2, 3, 4, 5, 6, 8 and 10, whereas TM did not appear in either TLR7 and TLR9 of GX buffaloes, which was similar to NR river-type buffaloes, and agreed with the prediction result obtained by SMART analysis. The biological relevance of the absence of a TM domain in bubaline TLR7 compared to other ruminant species remains to be elucidated.

Additionally, to further characterize the tertiary structure, protein homology models for these GX buffalo TLRs were generated by applying the SWISS-MODEL Homology Modelling program (see Additional file 8: 
Figure S5). The 3D graphics may provide information for further predictions on the active domain of proteins to help design appropriate ligands or reagents. The QMEAN4 ranged between -2.22 and -7.28 , while GMQE score ranged between 0.55 and 0.77 (if excluding TLR10 which found unmatched template of TLR10 from the database), indicating an overall good quality for most models (see Additional file 9: Table S4).Although this is a rough analysis of homologues for 3D structure for these bubaline TLRs, it has however been revealed that all 3D models for these TLR proteins were closely matched to the homologous TLR templates (with the exception of TLR10), what preliminarily suggests their conservation of tertiary structure therefore the possible biology to those of template TLRs that have been commonly studied.

\section{Evolution of ruminant TLR genes, TIR and LRR domains}

The phylogenetic tree revealed the relative genetic distance between different ruminant species, especially between the two types of buffaloes examined in our study. The AA sequences of TLRs 1-10 from GX buffaloes, NR buffaloes and the examined ruminant species, were subjected to phylogenetic analysis using the $\mathrm{NJ}$ algorithm with 1,000 bootstrap resampling (Fig. 3a). The same analysis was used for TIRs and LRRs (Fig. 3b and c). It is clear that clustering of major TLR gene subfamilies with high bootstrap values, could be divided into three clades: TLR1 subfamily (TLRs 1, 2, 6 and 10), TLR7 subfamily (TLRs 7, 8 and 9), and the singletons (TLRs 3, 4 and 5) together as a single clade originating from the same branch.

Regarding the singleton TLRs (TLRs 3, 4 and 5), GX buffalo TLR4 and TLR5, but not TLR3, were highly conserved between the two buffalo breeds - compared with species of genus Bos or Bison. There was a higher similarity between TLR2 or TLR8 of goats with GX buffaloes, but not with river-type buffaloes or any Bos species. An additional phylogenetic analysis of TLR AA sequences - comparing the evolutionary relationship of GX buffaloes, major ruminant species and non-ruminant mammals -revealed a closer relationship of GX buffalo TLRs to those of ruminants than to other mammalian TLRs (see Additional file 10: Figure S6), a finding consistent with previous studies(Banerjee et al. 2012; Dubey et al. 2013).

\section{mRNA expression in selected tissues from GX buffaloes}

Transcripts of TLRs 1-10 genes and the reference gene GAPDH were successfully quantified in all examined tissues and blood leukocytes of GX buffaloes using a more sensitive SYBR Green dye-based RT-qPCR assay. The expected size of the amplified products was verified by electrophoresis (Fig. 1b). The results of tissue-specific TLRs 1-10 expression levels are shown in Fig. 4. Our expression analysis of leukocytes showed that relative TLR4 expression was significantly higher than any other TLR in leukocytes $(p<0.0001)$, and then the expression of TLR4 in all other examined tissues $(p<0.0001)$. Other TLRs in leukocytes showed low expression levels, among which TLRs 5, 6 and 9 had the lowest expression levels.

Among all examined organs and tissues, TLR1 expression was highest in HLNs and lowest in the lungs. The highest expression level of TLR2 was in the heart $(p<0.0001)$ and the lung $(p<0.01)$, and lowest expression was in the liver. TLR2 expression in SILN $(p<0.05)$, heart $(p<0.0001)$, lung $(p<0.01)$, and 
kidney $(p<0.05)$ was significantly higher than any other TLR in the same group, except TLR1 and TLR10 in the kidney. TLR3 had relatively mild or moderate expression levels in all tissues. TLR4 expression in spleen was significantly higher than TLR5 $(p<0.01)$, TLR6 $(p<0.05)$, TLR9 $(p<0.01)$, and TLR10 $(p<$ $0.05)$. In MLN and spleen, higher expression values of TLR4 $(p<0.01)$ were found, as well as relatively higher expression of TLR7 and TLR8 mRNAs, compared to all other tested tissues.

\section{Discussion}

We have characterized, for the first time, TLRs 1-10 genes of GX buffaloes -the most popular buffalo's breed in a major buffalo-producing country, China. We also compared the characteristic features of TLRs 1-10 in Chinese GX buffaloes to those of other river-type buffalo's breeds, and other ruminant and nonruminant species. The studies described herein demonstrate that the sequence diversity of TLR genesis conserved across ruminant species, and that distinct phylogenetic clusters of TLRs 1-10 genes exist between different breeds of buffaloes. Furthermore, the protein structure of GX buffalo TLRs 1-10 has also been analyzed by using a series of available bioinformatics tools in this study. Predicting the protein structure will provide basic information especially for further molecular docking which predicts the preferred orientation, binding affinities and signaling cascades for buffalo TLRs to ligands, and is meaningful for posing structural hypotheses of how some pathogenic ligands inhibit TLRs, in the aims to select or design correct TLR antagonist or agonist (Gupta et al. 2018; Tao et al. 2020).

Our evolution tree analyses here concur with a similar study about river-type buffaloes and other reported species, supporting the case for conservation of TLRs. Within the TLR1 and TLR7 subfamilies, GX buffaloes and NR buffaloes were found to be closely related, compared to species of the genus Bos or Bison, except TLR6 and TLR9. With respect to TLR 6 and TLR 9, GX buffaloes were more related to genus Bos; while river-type buffaloes were closer to goat and sheep, as shown in a previous study(Dubey et al. 2013). The involvement of TLR6 and TLR9 in susceptibility to pulmonary tuberculosis has been shown (Song et al. 2014; Chen et al. 2015; Verma et al. 2016). The closer relationship of TLR6 and TLR9 between swamp-type buffaloes and cattle, but not river-type buffaloes, may be attributed to natural selection that drives genetic changes and differential innate immune responses in order to provide resistance to specific endemic infections (le Roex et al. 2017).

A phylogenetic analysis, based on TIR or LRR alone, also broadly conformed to the finding shown in the AA sequence tree. However, unlike the tree based on complete AA sequences, the TIR domain of GX TLR9 seems separated from TLR7 subfamily as a single clade; whereas the LRR domain of GX TLR4 was also separated from the TLR3 and TLR5 branch. Interestingly, LRR domains of GX buffalo TLRs 3, 6 and 9, showed a closer relationship with species of Bos and Bison in the tree; whereas NR buffalo LRRs 3, 6 and 9 clustered with goat and/or sheep, a result also reported previously (Dubey et al. 2013). Phylogenetic analysis of the TIR or LRR domains provided more insights across ruminant species. These variations suggest possible differences in the mechanism of pathogen recognition between swamp-type buffaloes and river-type buffaloes. 
As known, the mRNA expression profiles of TLRs have been successfully determined in human, mice (Rehli 2002; Nishimura and Naito 2005), chicken (Fukui et al. 2001; lqbal et al. 2005), cattle (Menzies and Ingham 2006), sheep (Menzies and Ingham 2006; Chang et al. 2009), goats (Tirumurugaan et al. 2010; Paul et al. 2015), and river-type buffaloes (le Roex et al. 2017; Vahanan et al. 2008). However, there are no reports about the tissue abundance of TLR mRNA levels in swamp-type buffalo as yet, what may limit many scientific researches on buffaloes that are based on the normal expression pattern of TLRs in bubaline organs. Understanding the overall tissue-specific expression patterns of TLRs in buffaloes can be used to generate focused hypotheses on the regulation of the tissue-specific expression of TLR isoforms and TLR signaling, thereby be helpful for else possible researches and application on water buffaloes. In the river-type buffaloes, expression of TLRs 1-10 (excluding TLR3) was detected in neutrophils, spleen, heart, lung and liver by using conventional PCR followed by agarose gel electrophoresis - which is considered semi-quantitative and less accurate approach. Our study used RTqPCR as a more accurate tool to quantify the expression pattern of TLRs in buffalo tissue, provides some more useful data for future studies related to TLR signaling pathways.

Of particular interest was the assessment of the TLRs mRNA expression in blood leukocytes, liver and $M L N$, because these are important immune related tissues, which are more likely to be affected during infection with Fasciola species. Here, we found that TLR4 expression was significant in leukocytes, as well as in most examined organs. TLR4 is widely-expressed in leukocytes, mainly macrophages, and induces Th1 cytokine production, which provokes inflammatory response through binding with LPS (lipopolysaccharide) of Gram-negative bacteria and fungi (Romagne 2007; Blum et al. 2017), or via specific lipid-like structure of bacteria and viruses (Novák 2014). TLR4 dynamics in brucellosis and tuberculosis in cattle and buffaloes, have been described in previous in vivo and in vitro studies (Mucha et al. 2009; Alfano et al. 2014; Prakash et al. 2014; Singh 2015; Bhaladhare et al. 2016). The activation and plasticity of pathogen-sensitized macrophages have been associated with a TLR4-dependent receptor pathway (Martin 2000; Harju et al. 2001; Mukhopadhyay et al. 2004; Werling et al. 2006; Martinez and Gordon 2014), indicating that high TLR4 expression may play a role in mediating innate immunity during infection. Further investigations on TLR4 in buffalo immune cells should be at the top of the priority list.

In the present study, we found that TLR genes are differentially expressed across various tissues of normal swamp buffaloes, as reported previously in river-type buffaloes (Banerjee et al. 2012). The mRNA level of TLRs in MLNs was the highest among the three examined lymph nodes, reflecting a high level of antigen-driven activation. TLR3 had relatively mild or moderate expression levels in all tissues, in agreement with the result reported in Indian buffaloes (Vahanan et al. 2008), indicating that the expression pattern of TLR3 may be the same in bubaline tissues - regardless of breed. Higher expression of TLR4 in MLN and spleen (when comparing to all other tissue types in our study) may probably because of that these tissues have relatively high numbers of macrophages and are more likely to come in contact with and respond to bacterial products (Fernández-Santoscoy et al. 2015). In addition, the abundant expression of TLR7/8 mRNA in MLN and spleen may reflect antiviral/antibacterial activities of TLR7 and TLR8 (Takedaet al. 2003; Vahanan et al. 2008; Petzke et al. 2009; Goyal et al. 2014; Bhattarai et 
al. 2018). Surprisingly, TLR5 mRNA fell to barely detectable in all tissues in our study. According to the literature research, the abundance of transcripts of TLR5 was also very low in river-type buffaloes (Vahanan et al. 2008). Further study aimed to find answer for the limited TLR5 expression in buffalo tissue, may possibly bring some surprising discovery about the unclear bubaline immunology. Overall, these findings indicate that tissue-specific gene expression profile of TLRs 1-10 in GX buffaloes share similarities as well as differences to those in river-type buffaloes. It is reasonable to assume that the differential expression patterns of TLR genes in buffalo's tissues can impart the different activities of the TLRs and the diverse repertoire of immune response of buffalo's tissues.

\section{Conclusions}

We have carried out the first characterization of the full sequences of 10 TLR genes of the Chinese swamp-type buffaloes (GX breed). Sequence comparison between TLRs of Chinese swamp-type and Indian river-type buffaloes, revealed differences within the intracellular TIR domains and repeat number of different TLRs-which may underpin breed-specific differences in susceptibility to infection. We extended our analysis to include comparative quantification of TLRs 1-10 mRNA expression, across various tissues of swamp-type buffaloes using RT-qPCR, that found the relatively much higher expression of TLR2 in the heart and the lung, and TLR4 in leukocytes and the MLN. These results can facilitate further investigations of the molecular function of TLRs in buffaloes. Future work should involve examination of the correlation between gene expression and protein abundance in the buffaloes' tissues, and testing of the association between genetic polymorphism in TLRs and the pattern of inflammatory cytokines produced during specific infections. Other works focusing on the tertiary structure of TLR molecules should focus on determining the function of mutant sites, which may further reveal their contribution to immunity specifically in swamp-type buffaloes.

\section{Methods}

\section{Experimental animals}

Four female, two-year-old, GX buffaloes (352 \pm 13.81 kilogram) were purchased from local breeders in Nanning, Guangxi, China. The river-type buffalo's breeds (NR and Murrah; $n=4$ animals per breed) from buffalo's herds at Guangxi Buffalo Research Institute were used as a control for morphological identification. Commercial feed and clean water were provided ad libitum. Animals were treated with triclabendazole, penicillin/streptomycin and ivermectin, following the manufacturer's standard dosing regimens, in order to exclude the impact of any pre-existing infection on the expression of TLR genes. Treatment was followed by a 3-week withdrawal period, and animal tested major pathogens (parasites and microbes) - free was allowed to be used for the further experiments. All buffaloes survived the treatment and were euthanized at the end of the experiment, following sample collection for the designed purpose. Euthanasia was performed by head stunning using a captive bolt pistol producing immediate unconsciousness, and exsanguination. Experimental procedures were reviewed and approved by the Animal Ethics Committee of Guangxi University. All animals used in the study were handled in 
accordance with good animal husbandry practices, as per the Animal Ethics Procedures and Guidelines of the People's Republic of China.

\section{Identification of buffaloes}

Identification of the phenotypic features of the animals was performed according to reference textbooks (Zhang et al. 2000). Additionally, karyotyping analysis was performed as described previously (Bongso and Hilmi 1982). Briefly, $1 \mathrm{~mL}$ of peripheral blood from each GX buffalo was mixed with $10 \mathrm{~mL}$ of RPMI 1640 culture medium supplemented with $20 \%$ fetal bovine serum (FBS), $0.05 \mathrm{~mL}$ penicillin/streptomycin, and $0.1 \mathrm{~mL}$ of phytohemagglutinin (PHA) as a mitogen, and incubated at $37^{\circ} \mathrm{C}$ with $5 \% \mathrm{CO}_{2}$. All reagents used for cell culture were purchased from GIBCO (Thermo Fisher Scientific, US). After $72 \mathrm{~h}, 0.2 \mu \mathrm{g} / \mathrm{mL}$ of colchicine was added and cells were harvested, followed by addition of a pre-warmed hypotonic solution $(75 \mathrm{mM} \mathrm{KCl})$ and incubation for $15-20 \mathrm{~min}$ at $37^{\circ} \mathrm{C}$. The cell suspension was centrifuged at $1,000 \times \mathrm{g}$ for 5 min and the cell pellet was fixed with methanol: acetic acid in a ratio of $3: 1(\mathrm{v} / \mathrm{v})$ for $30 \mathrm{~min}$. The cell suspension was dropped onto clean, chilled glass slides and dried for $2 \mathrm{~h}$ in an oven; this was followed by Giemsa staining to determine the diploid numbers and morphological characteristics of each karyotype using a Nikon-80i microscope (Nikon, Japan). For further analysis of the chromosomes, metaphase plates were photographed, and images were enlarged, cropped and arranged into four groups according to their size and shape using Genikon karyotype auto-analysis software (Nikon, Japan).

\section{Sample collection}

Whole blood from all four GX buffaloes were collected postmortemly and used for extraction of genomic DNA (gDNA) and mtDNA D-loop sequence analysis as described below. Also, blood leukocytes and tissue samples were collected from four GX breed buffaloes and used for RNA isolation and gene expression analysis. Leukocytes were isolated from EDTA-treated blood samples using Ficoll gradient centrifugationbased kit (TBD Science, Tianjin, China), and cultured in high-glucose Dulbecco's modified eagle medium (DMEM), supplemented with $20 \%$ FBS and $1 \%$ penicillin-streptomycin solution for 2 days. Leukocytes used for gDNA analysis were stored at $-80^{\circ} \mathrm{C}$, whereas leukocytes used for RNA analysis were suspended in $1 \mathrm{~mL}$ of RNAiso (TaKaRa, Dalian, China) per $10^{8}$ cells, and stored at $-80^{\circ} \mathrm{C}$ until analysis. Postmortem tissue collection of heart, liver, spleen, lung, kidney, hepatic lymph node (HLN), mesentery lymph node (MLN), superficial inguinal lymph nodes (SILN) was also performed. Tissue samples were cut into small $(5 \mathrm{~mm} \times 5 \mathrm{~mm}$ ) pieces, snap frozen in liquid nitrogen in RNA Store solution (Tiangen Biotech, China) and kept at $-80^{\circ} \mathrm{C}$ until analysis.

\section{Amplification, cloning and sequencing of mtDNA and TLRs}

gDNA was extracted using a tissue genomic DNA extraction kit (Tiangen, Beijing, China) according to the manufacturer's instructions. To analyze the mitochondrial DNA (mtDNA) D-loop region of GX buffaloes, gDNA was amplified using primers CB1: 5'-TAGTGCTAATACCAACGGCC-3' and CB2: 5'-

AGGCATTTTCAGTGCCTTGC-3' (Kierstein et al. 2004). To analyze the GX buffalo's TLR gene sequences, specific primers for bubaline TLRs 1-10 gene coding sequence (CDS) were designed based on full-length 
sequences of Indian river buffalo TLRs 1-10 using Primer 3 software (Rozen and Skaletsky 2000; Dubey et al. 2013). All primers listed in Table 1 were synthesized by General BioSystems (Anhui, China). For each amplification reaction, the template gDNA $(1 \mu \mathrm{g})$ was amplified in a total reaction volume of $25 \mu \mathrm{l}$ containing $1 \mu \mathrm{M}$ of each primer and 2.5 units of TransTaq DNA Polymerase High Fidelity (TransGen Biotech, Beijing, China). The reaction was performed in a thermal cycler (S100 Mastercycler, Bio-Rad, USA) with an initial denaturation at $94^{\circ} \mathrm{C}$ for 5 min; followed by 38 cycles of denaturation at $94^{\circ} \mathrm{C}$ for $1 \mathrm{~min}$, annealing at $72{ }^{\circ} \mathrm{C}$ for $1 \mathrm{~min}$ and extension at $72{ }^{\circ} \mathrm{C}$ for $1 \mathrm{~min}$, with a final extension of $5 \mathrm{~min}$ at $72{ }^{\circ} \mathrm{C}$. PCR products were visualized by electrophoresis at $120 \mathrm{~V}$ for $30 \mathrm{~min}$ on a $2 \%$ agarose gel (Biowest, Spain) containing a fluorescent dye. DNA Fragments were excised from the gel and purified using QIAquick gel purification kit (QIAGEN, US). Purified fragments of blunt-end PCR products were cloned into pMD 18-T vector using a PMD $^{\text {TM }} 18-T$ Vector Cloning Kit according to the manufacturer's instructions (TaKaRa, Dalian, China). Plasmid DNA was extracted from colonies using a QIAGEN Miniprep kit. Sequencing was performed by General Biosystems Inc (Anhui, China) using ABI 3700 and 3730 automated DNA sequencers (Applied Biosystems).

\section{RT-qPCR analysis of TLR gene expression}

Here, we determined the transcript abundance of TLRs 1-10 genes in leukocytes and various tissues from GX buffaloes. Frozen samples were homogenized in RNAiso Plus solution (TaKaRa, Dalian, China) and total RNA was extracted and purified using Ultrapure RNA Kit (CWbio, Beijing, China) according to the manufacturer's instructions. Quantity and purity of the isolated RNA were assessed using a Nanodrop 2000 spectrophotometer (Thermo Scientific, US). cDNA was synthesized from total RNA using HiScript ${ }^{\circledR}$ II Q Select RT SuperMix for qPCR (Vazyme, Nanjing, China). Briefly, $1 \mu \mathrm{g}$ of RNA in $8 \mu$ l of RNase-free water was mixed with $2 \mu \mathrm{l}$ of $4 \times \mathrm{gDNA}$ wiper mix, and incubated at $42^{\circ} \mathrm{C}$ for $2 \mathrm{~min}$ to remove genomic DNA. This was followed by addition of $2 \mu \mathrm{l}$ of $5 \times \mathrm{HiScript}{ }^{\circledR}$ II qPCR SuperMix II (containing buffer, dNTP, HiScript ${ }^{\circledR}$ II Reverse Transcriptase, RNase inhibitor and Randon primers/Oligo dT primer mix). cDNA was synthesized by incubation at $25^{\circ} \mathrm{C}$ for $10 \mathrm{~min}$, then $50^{\circ} \mathrm{C}$ for $30 \mathrm{~min}$, and the enzyme was inactivated at $85^{\circ} \mathrm{C}$ for 5 min.

cDNA was amplified by reverse transcription quantitative real time polymerase chain reaction (RT-qPCR) using the ChamQ ${ }^{\circledR}$ SYBR qPCR master mix (Vazyme Biotech, Nanjing, China) and a CFX96 real-time PCR instrument (Bio-Rad, US). The two-step RT-qPCR program was set as follows: initial denaturing at $95^{\circ} \mathrm{C}$ for $30 \mathrm{~s}$, followed by 40 cycles at $95^{\circ} \mathrm{C}$ for $10 \mathrm{~s}$, and $60{ }^{\circ} \mathrm{C}$ for $30 \mathrm{~s}$. To verify the presence of a single amplification product, without primer dimers, a melting-curve was obtained at the end of each run. The relative mRNA expression levels of all TLRs 1-10 genes were normalized to those of glyceraldehyde-3phosphate dehydrogenase (GAPDH) gene reference and calculated with $2^{-\Delta \mathrm{Cq}}$ method. The primers used are listed in Table 2. The RT-qPCR experiments were performed in triplicate. Two-way analysis of variance (ANOVA) and least-significant-difference (LSD) post-hoc test were performed using GraphPad Prism 6.02 (GraphPad Software Inc, La Jolla, CA, USA) to determine significance in comparisons of mean expression levels of buffalo's TLRs 1-10 per tissue (indicated by *) and in comparisons of mean expression levels across leukocyte and tissue samples (indicated by \#). 
Table 2

Primer sequences used for RT-qPCR analysis

\begin{tabular}{|c|c|c|}
\hline TLR & Primer sequence $\left(5^{\prime} \text { to } 3^{\prime}\right)^{a}$ & Product size (bp) \\
\hline \multirow[t]{2}{*}{ TLR1 } & F: TGCCTGGGTGAAGAATGAAT & 166 \\
\hline & R: CTGGACAAAGTTGGGAGACA & \\
\hline \multirow[t]{2}{*}{ TLR2 } & F: CTGGGCTGTAATCATCCTGT & 167 \\
\hline & R: AGGTGATCTCGTTGTTGGAC & \\
\hline \multirow[t]{2}{*}{ TLR3 } & F: CATTTCACTGACTTCGCTCC & 175 \\
\hline & R: AGTCCGCAAACTTGAGAAGG & \\
\hline \multirow[t]{2}{*}{ TLR4 } & F: GGTTCAAACTTCGTGGGCTT & 109 \\
\hline & R: AGCGGAGGTTTCTGAGTGAT & \\
\hline \multirow[t]{2}{*}{ TLR5 } & F: GAAACTTCAGCAATGCCATC & 295 \\
\hline & R: TTGAGAACTTGGAGGTTGTC & \\
\hline \multirow[t]{2}{*}{ TLR6 } & F: TGCCGGAAGATTAGGTCCCT & 186 \\
\hline & R: TCAGATACCTGGAAGTCCTT & \\
\hline \multirow[t]{2}{*}{ TLR7 } & F: ATTTCTGGGATGTGTGGTAT & 186 \\
\hline & R: TAAAACACTTCTCTCTCGGG & \\
\hline \multirow[t]{2}{*}{ TLR8 } & F: TGAGACGCTACTGCTGAGTG & 147 \\
\hline & R: TTGGTGGCGGTCTTCGTTTC & \\
\hline \multirow[t]{2}{*}{ TLR9 } & F: TTCAACTGGAGCAGCCTGAC & 149 \\
\hline & R: ATCACGAAGCCGATGCTGTT & \\
\hline \multirow[t]{2}{*}{ TLR10 } & F: GCAACACATCCCTGAGGCAC & 150 \\
\hline & R: TGTTTCTAGGCAAGCACCTG & \\
\hline \multirow[t]{2}{*}{ GAPDH } & F: CCTGCACCACCAACTGCTTG & 223 \\
\hline & R: TTGAGCTCAGGGATGACCTTG & \\
\hline
\end{tabular}

\section{Bioinformatics analysis}

To identify the genotype of GX buffaloes, the mtDNA D-loop sequence was compared with five published sequences of swamp-type Chinese buffaloes obtained from the National Center of Biotechnology 
Information (NCBI) database. These included Wen-zhou (WZ DQ364160), Xing-long (XL, DQ364180), Decheng (DC, EF053536), Xin-yang (XY, DQ364166), and Fu-an (FA, DQ364175). The mtDNA D-loop sequences of $\mathrm{GX}$ buffaloes were also compared to five Brazilian/Indian/Italian river-type buffalo haplotypes: Nili-Ravi (GQ166716.1), Murrah (AF475204), Surti (EF121707), Mediterranean (AF197199) and Jaffarabadi (AF197196). The mtDNA D-loop sequences of species of genus Bos and genus Bison were used as outgroups. These included Bison bison (American bison, U12864.1), Bos grunniens (yak, AY374125.1), Bos indicus (zebu, DQ887761.1), Bos frontalis (Chinese gayal, HM215205.1; Indian gayal, HM215207.1) and Bos mutus (wild yak, KM280683.1). The relevant TLR gene sequences of NR buffalo (river-type), cattle, American bison, zebu, yak, wild yak, gayal, goat and sheep were also obtained from NCBI GenBank database, and were used for multiple alignment and construction of phylogenetic trees for TLR CDSs, and analysis of Toll/IL-1 receptor (TIR) domains and leucine-rich repeat (LRR) domains of GX buffaloes in relation to other ruminant species. The accession numbers are listed in Table 3.

Raw sequences were edited using CHROMAS software (Version 2.6.4, http://technelysium.com.au/wp/chromas). The amino acids (AA) sequence analysis and structural prediction of TLRs 1-10 of GX buffaloes were performed using various bioinformatics software. The Open Reading Frame (ORF) Finder (http://www.ncbi.nlm.nih.gov/projects/gorf/orfig.cgi) was used to analyze the CDS regions of TLR AA sequences. Various physio-chemical properties, including amino acid composition, theoretical isoelectric point ( $\mathrm{pl})$, instability index and molecular weight (MW), were evaluated using ExPASy-ProtParam online server (http://us.expasy.org/tools/protparam.html) (Gasteiger et al. 2005).

Analysis of the protein motif was performed using the genomic mode of the Simple Modular Architecture Research Tool (SMART) (http://smart.embl-heidelberg.de/) (Letunic and Bork 2018). Analysis of AA composition and sequencing of the putative product encoded by TLRs 1-10 genes of GX buffaloes were performed using the DNASTAR program of LASERGENE software and ExPASy-ProtParam tool, whereas hydrophobicity was analyzed using the ExPASy-ProtScale tool (http://www.expasy.ch/tools/protscale.html) (Gasteiger et al. 2005). The AA sequences of TLRs 1-10, and their respective TIR and LRR domains of GX buffaloes and various ruminant species, were subjected to multiple alignment analysis; and the percent identity was estimated using the MEGALIGN program of LASERGENE software.

Variation in repeat number and location of LRR regions in TLRs were determined by the LRR finder webbased program from a LRR database (LRR db) (Offord and Werling 2013). TMHMM Server 2.0 (http://www.cbs.dtu.dk/services/TMHMM-20/) (Krogh et al. 2001) was used to predict transmembrane helices. Signal peptide cleavage sites were analyzed by SignalP 4.1 Server (http://www.cbs.dtu.dk/services/SignalP/) (Petersen et al. 2011) and SMART. The sub-cellular localization of each TLR protein was predicted with PredictProtein 1.0 Server (https://www.predictprotein.org/), TargetP 1.1 Server (http://www.cbs.dtu.dk/services/TargetP/) and ProtComp 9.0 Server (http://linux1.softberry.com/) (Emanuelsson et al. 2000; Yachdav et al. 2014; Jing et al. 2017). The preliminary tertiary structure of each buffalo TLR protein was analyzed by SWISS-MODEL 
(https://www.swissmodel.expasy.org/)by aligning the target sequence to a template structure from its protein data bank and building a 3D model, as well as evaluating the quality of the model (Waterhouse et al. 2018).

We also performed comparative and phylogenetic analysis of the mtDNA D-loop nucleotide sequences and AA sequences of TLRs, TIRs and LRRs among animal species. Neighbor-joining $(\mathrm{NJ})$ trees were constructed using the Kimura's two-parameter model, with 1,000 bootstrap replications using Molecular Evolution and Genetic analysis software MEGA version 6 (Tamura et al. 2013).

\section{Abbreviations}

TLR: Toll-like receptor; NR: Nili-Ravi; GX: Guangxi; PAMP: pathogen associated molecular pattern; PRR: pattern recognition receptor. NCBI: National Center of Biotechnology Information; gDNA: genomic DNA; cDNA: complementary DNA; mRNA: massager RNA; mtDNA: mitochondria DNA; LSD: least-significantdifference. GAPDH: glyceraldehyde-3-phosphate dehydrogenase; NJ: Neighbor-joining. pl: isoelectric point; DMEM: Dulbecco's modified eagle medium; HLN: hepatic lymph node; MLN: mesenteric lymph node; SILN: superficial inguinal lymph nodes; CDS: coding sequence; $A A(a a)$ : amino acid; SP: signal peptide; SMART: simple modular architecture tool. TM: transmembrane; TIR: Toll/IL-1 receptor; LRR: leucine-rich repeat; MyD88: myeloid differentiation factor 88; TRIF: TIR domain-containing adaptor inducing interferon; TRAM: TRIF-related adaptor molecule; TIRAP: TIR domain containing adaptor protein; ORF: open reading frame; FMD: foot-and-mouth disease; FBS: fetal bovine serum; PHA: phytohemagglutinin.

\section{Declarations}

\section{Ethics approval and consent to participate}

The study design was reviewed and approved by the Animal Ethics Committee of Guangxi University. Animals used in the study were handled in accordance with good animal practices as required by the Animal Ethics Procedures and Guidelines of the People's Republic of China.

\section{Consent for publication}

Not applicable.

\section{Availability of data and materials}

The datasets used and/or analyzed during the current study are available from the corresponding author on reasonable request.

\section{Competing interests}

The authors declare that they have no potential conflicts of interest. 


\section{Fundings}

This study was financially supported in part by the National Natural Science Foundation of China (Grant No. 31260605), the National Key Basic Research Program (973 Program) of China (Grant No. 2015CB150300) and the Scientific Research Fund of Guangxi Education Department (Grant No. KY2016YB040). Funders had no role in the design of the study and collection, analysis, and interpretation of data and in writing the manuscript.

\section{Author's contributions}

WS, XFM, YQK, HME, XQZ and WYH conceived and designed the study, and critically revised the paper. WS, XFM, YQK and HME contributed to the writing of the manuscript. YRW assisted the revision. ZAS, $\mathrm{CHH}, \mathrm{KJL}, \mathrm{YRW}$ and DYW prepared the experimental samples. WS, YQK and $\mathrm{CHH}$ performed the experimental procedures. WS, XFM and YQK analyzed the results. WS, XFM and YQK contributed analysis tools. All authors read and approved the final manuscript.

\section{Acknowledgements}

The authors would like to thank Yao-Bao Wei, Yu Zhang, Zhi-Yong Wei, Wen-Ping Zhao and Qing-Hua Chang from the Laboratory of Veterinary Parasitology, Guangxi University, and Xiao-Xuan Zhang, Wen-Bin Zheng and Jian-Gang Ma from Lanzhou Veterinary Research Institute, Chinese Academy of Agricultural Sciences, for technical assistance.

\section{References}

1. Alfano F, Peletto S, Lucibelli MG, Borriello G, Urciuolo G, Maniaci MG et al. (2014) Identification of single nucleotide polymorphisms in Toll-like receptor candidate genes associated with tuberculosis infection in water buffalo (Bubalus bubalis).BMC Genet 15:139.

2. Angeles JMM, Leonardo LR, Goto Y, Kirinoki M, Villacorte EA, Hakimi H et al. (2015) Water buffalo as sentinel animals for schistosomiasis surveillance.BWorld Health Organ 93:511-

3. Astakhova NM, Perelygin AA, Zharkikh AA, Lear TL, Coleman SJ, MacLeod JN et al. (2009) Characterization of equine and other vertebrate TLR3, TLR7, and TLR8 genes.Immunogenetics 61:529-

4. Banerjee P, Gahlawat SK, Joshi J, Sharma U, Tantia MS, Vijh RK(2012) Sequencing, Characterization and Phylogenetic analysis of TLR genes of Bubalus bubalis.DHR-IJBLS 3:137-

5. Bhaladhare A, Sharma D, Kumar A, Sonwane A, Chauhan A, Singh R et al. (2016) Single nucleotide polymorphisms in toll-like receptor genes and case-control association studies with bovine tuberculosis. Vet World 9:458.

6. Bhattarai D, Worku T, Dad R, Rehman ZU, Gong XL, Zhang SJ (2018) Mechanism of pattern recognition receptors (PRRs) and host pathogen interplay in bovine mastitis.MicrobPathogenesis 120:64- 
7. Björklund ÅK, Ekman D, Elofsson A(2006) Expansion of protein domain repeats.PLoS Comput Biol 2:114.

8. Blum SE, Heller ED, Jacoby S, Krifucks O, Leitner G(2017) Comparison of the immune responses associated with experimental bovine mastitis caused by different strains of Escherichia coli. JDairy Res 84:190-

9. Bongso TA, Hilmi M. (1982) Chromosome banding homologies of a tandem fusion in river, swamp, and crossbred buffaloes (Bubalus bubalis). CanJGenetCytol 24:667-

10. Chang JS, Russell GC, Jann O, Glass EJ, Werling D, Haig DM(2009) Molecular cloning and characterization of Toll-like receptors 1-10 in sheep.Vet Immunol Immunop127:94-

11. Chen C, He ZB, Zhang M, Chen SY, Lan RX, Wang J et al. (2014) Expression pattern of Toll-like receptors (TLRs) in different organs and effects of lipopolysaccharide on the expression of TLR 2 and 4 in reproductive organs of female rabbit. Dev Comp Immunol 46:341-

12. ChenZ, Wei W, Liang JQ, Wang JH, Feng SS, Zhang GY(2015) Association between toll-like receptors 9 (TLR9) gene polymorphism and risk of pulmonary tuberculosis: meta-analysis. BMC Pulm Med 15:57.

13. Cockrill WR (1976) The buffaloes of China. FAO of UN, Rome.

14. Degrandi TM (2010) Cytogenetic characterization of swamp ( bubaliskerebau) and river (B. bubalis bubalis) buffaloes and respective progeny. Rev Vet 21:358-362.

15. Dubey PK, Goyal S, Kathiravan P, Mishra BP, Gahlawat SK, Kataria RS (2013) Sequence characterization of river buffalo Toll-like receptor genes 1-10 reveals distinct relationship with cattle and sheep.Int Jlmmunogenet 40:140-

16. Emanuelsson O, Nielsen H, Brunak S, Heijne GV(2000) Predicting subcellular localization of proteins based on their N-terminal amino acid sequence.J Mol Biol 300:1005-

17. Fernández-Santoscoy M, Wenzel UA, Yrlid U, Cardell S, Bäckhed F, Wick MJ (2015) The gut microbiota reduces colonization of the mesenteric lymph nodes and IL-12-independent IFN- $Y$ production during salmonella infection. Frontcell Infect Mi 5:93.

18. Fukui A, Inoue NK, Matsumoto M, Nomura M, Yamada K, Matsuda Y et al. (2001) Molecular cloning and functional characterization of chicken toll-like receptors A single chicken toll covers multiple molecular patterns.JBiolChem 276:47143-

19. Gasteiger E, Hoogland C, Gattiker A, Wilkins MR, Appel RD, Bairoch A (2005) Protein identification and analysis tools on the ExPASy server.In: Walker JM (eds) The proteomics protocols handbook, Humana Press: New York. pp 571-

20. Goraya MU, Abbas M, Ashraf M, Munir M (2015) Isolation of buffalo poxvirus from clinical case and variations in the genetics of the B5R gene over fifty passages.Virus Genes51:45-

21. Goyal S, Dubey PK, Kumari N, Niranjan SK, Kathiravan P, Mishra BP et al. (2014) Caprine Toll-like receptor 8 gene sequence characterization reveals close relationships among ruminant species.Int $J$ Immunogenet 41:81- 
22. GuptaM, Sharma R, Kumar A (2018) Docking techniques in pharmacology: How much promising? Comput Biol Chem 76:210-

23. Harju K, Glumoff V, Hallman M (2001) Ontogeny of Toll-like receptors TIr2 and TIr4 in mice.Pediatr Res 49:81-

24. Hassan AS, Garba SM, Gumel AB, Lubuma JMS (2014) Dynamics of Mycobacterium and bovine tuberculosis in a human-buffalo population.Comput Math Method M2014:912306 10.1155/2014/912306.

25. Hopkins PA, Sriskandan S (2005) Mammalian Toll-like receptors: to immunity and beyond.ClinExplmmunol 140:395-

26. Iqbal M, Philbin VJ, Smith AL (2005) Expression patterns of chicken Toll-like receptor mRNA in tissues, immune cell subsets and cell lines.Vet Immunol Immunop 104:117-

27. Iwasaki A, Medzhitov R (2015) Control of adaptive immunity by the innate immune system.Nat Immunol 16:343.

28. Jing L, Guo DD, Hu WJ, Niu XF (2017) The prediction of a pathogenesis-related secretome of Puccinia helianthi through high-throughput transcriptome analysis.BMC Bioinformatics 18:166.

29. KällL, Krogh A, Sonnhammer ELL (2004) A combined transmembrane topology and signal peptide prediction method. J Mol Biol 338:1027-

30. Kawai T, Akira S (2010) The role of pattern-recognition receptors in innate immunity: update on Tolllike receptors. Nat Immunol 11:373.

31. Kierstein G, Vallinoto M, Silva A, Schneider MP, lannuzzi L, Brenig B (2004) Analysis of mitochondrial D-loop region casts new light on domestic water buffalo (Bubalus bubalis) phylogeny.Mol Phylogenet Evol 30:308-

32. Klous G, Huss A, Heederik DJJ, Coutinho RA(2016) Human-livestock contacts and their relationship to transmission of zoonotic pathogens, a systematic review of literature. One Health, 2:65-

33. Kobe B, Deisenhofer J (1994) The leucine-rich repeat: a versatile binding motif.Trends Biochem Sci 19:415-

34. Kobe B, Kajava AV (2001) The leucine-rich repeat as a protein recognition motif.Curr Opin Struc Biol $11: 725-$

35. Krogh A, Larsson B, Heijne GV, Sonnhammer ELL (2001) Predicting transmembrane protein topology with a hidden Markov model: application to complete genomes.J Mol Biol 305:567-

36. Kumar S, Nagarajan M, Sandhu JS, Kumar N, Behl V, Nishanth G (2007) Mitochondrial DNA analyses of Indian water buffalo support a distinct genetic origin of river and swamp buffalo.Anim Genet 38:227-

37. le Roex N, Jolles A, Beechler B, Helden PV, Hoal E (2017) Toll-like receptor (TLR) diversity influences mycobacterial growth in African buffalo.Tuberculosis 104:87-

38. Lei CZ, Zhang W, Chen H, Lu F, Liu RY, Yang XY et al.(2007) Independent maternal origin of Chinese swamp buffalo (Bubalus bubalis).Anim Genet 38:97- 
39. Letunic I, Bork P (2018) 20 years of the SMART protein domain annotation resource.Nucleic Acids Res 46:493-

40. Martin TR (2000) Recognition of bacterial endotoxin in the lungs. Am J RespCell Mol 23:128-

41. Martinez FO, Gordon S (2014) The M1 and M2 paradigm of macrophage activation: time for reassessment. F1000Prime Rep6:13.

42. Matsushima N, Tanaka T, Enkhbayar P, Mikami T, Taga M, Yamada Ket al. (2007) Comparative sequence analysis of leucine-rich repeats (LRRs) within vertebrate toll-like receptors.BMC Genomics 8:124.

43. Menzies M, Ingham A (2006) Identification and expression of Toll-like receptors 1-10 in selected bovine and ovine tissues. Vet Immunol Immunop 109:23-

44. Miguel E,Grosbois V,Fritz H,Caron A, de Garine-Wichatitsky M, Nicod F et al. (2017) Drivers of footand-mouth disease in cattle at wild/domestic interface: Insights from farmers, buffalo and lions.DiversDistrib 23:1018-

45. Minakshi P,Ranjan K,Pandey N,Dahiya S,Khurana S,Bhardwaj N et al.(2015) Predominance of G10 genotype of rotavirus in diarrheic buffalo calves: a potential threat for animal to human zoonotic transmission.AdvAnimVetSci 3:16-

46. Mucha R, Bhide MR, Chakurkar EB, Novak M, Mikula Sr I (2009) Toll-like receptors TLR1, TLR2 and TLR4 gene mutations and natural resistance to Mycobacterium avium subsp. paratuberculosis infection in cattle. Vet Immunol Immunop 128:381-

47. Mukhopadhyay S, Peiser L, Gordon S (2004) Activation of murine macrophages by Neisseria meningitidis and IFN- $y$ in vitro: distinct roles of class A scavenger and Toll-like pattern recognition receptors in selective modulation of surface phenotype. J Leukocyte Biol 76:577-

48. Nguyen VVC, Le BC, Desquesnes M, Herder S, Nguyen PHL, Campbell JI et al. (2016) A Clinical and Epidemiological Investigation of the First Reported Human Infection With the Zoonotic Parasite Trypanosoma evansi in Southeast Asia.ClinInfectDis62:1002-

49. Nielsen H (2017) Predicting secretory proteins with SignalP. In: Cruz LM, Trefflich S, Weiss VA, Castro MAA (eds) Protein function prediction, Humana Press: New York. pp 59-

50. Nishimura M, Naito S (2005) Tissue-specific mRNA expression profiles of human toll-like receptors and related genes.BioPharmBull 28:886-

51. Novák K (2014) Functional polymorphisms in Toll-like receptor genes for innate immunity in farm animals. Vet Immunol Immunop 157:1-

52. Odeniran PO, Ademola IO (2016) Zoonotic parasites of wildlife in Africa: A review.Afr J WildlRes 46:1-

53. OffordV, Coffey TJ, Werling D (2010) LRRfinder: a web application for the identification of leucine-rich repeats and an integrative Toll-like receptor database.DevComplmmunol 34:1035-

54. Offord V, Werling D (2013) LRRfinder2.0: a webserver for the prediction of leucine-rich repeats. Innate Immun 19:398- 
55. Paul A, Dangi SS, Gupta M, Singh J, Thakur N, Naskar S et al. (2015) Expression of TLR genes in Black Bengal goat (Capra hircus) during different seasons. Small Ruminant Res 124:17-

56. Peter ME, Kubarenko AV, Weber ANR, Dalpke AH (2009) Identification of an N-terminal recognition site in TLR9 that contributes to CpG-DNA-mediated receptor activation.J Immunol 182:7690-

57. Petersen TN, Brunak S, Heijne GV, Nielsen H (2011) SignalP 4.0: discriminating signal peptides from transmembrane regions.Nat Methods 8:785.

58. Petzke MM, Brooks A, Krupna MA, Mordue D, Schwartz I (2009) Recognition of Borreliaburgdorferi, the Lyme disease spirochete, by TLR7 and TLR9 induces a type I IFN response by human immune cells.J Immunol183:5279-

59. Prakash O, Kumar A, Sonwane A, Rathore R, Singh RV, Chauhan A et al. (2014) Polymorphism of cytokine and innate immunity genes associated with bovine brucellosis in cattle.Mol Biol Rep 41:2815-

60. Presicce GA(2017) The Buffalo (Bubalus Bubalis)-Production and Research, 1st edn. Bentham Science Publishers: Sharjah.

61. Raja A, Vignesh AR, Mary BA, Tirumurugaan KG, Raj GD, Kataria R et al. (2011) Sequence analysis of Toll-like receptor genes 1-10 of goat (Capra hircus).Vet Immunol Immunop140:252-

62. Rehli M. (2002) Of mice and men: species variations of Toll-like receptor expression.Trends Immunol 23:375-

63. Rock FL, Hardiman G, Timans JC, Kastelein RA, Bazan JF (1998) A family of human receptors structurally related to Drosophila Toll. PNatl ASci 95:588-

64. Romagne F. (2007) Current and future drugs targeting one class of innate immunity receptors: the Toll-like receptors.Drug Discov Today 12:80-

65. Rozen S, Skaletsky H (2000) Primer3 on the WWW for general users and for biologist programmers.In: Misener S, Krawetz SA (eds) Bioinformatics methods and protocols, Humana Press: New Jersey. pp 365-

66. Shi DS, Wang J, Yang Y, Lu FH, Li XP, Liu QY (2012) DGAT1, GH, GHR, PRL and PRLR polymorphism in water buffalo (Bubalus bubalis). Reprod Domest Anim 47:328-

67. Shinkai H, Muneta Y, Suzuki K, Eguchi-Ogawa T, Awata T, Uenishi H (2006) Porcine Toll-like receptor 1,6 , and 10 genes: complete sequencing of genomic region and expression analysis.Mol Immunol 43:1474-

68. Singh J (2015) Differential miRNA profiling in diseased and healthy buffaloes.Ph.D Thesis, Guru Angad Dev Veterinary and Animal Sciences University.

69. Song Y, Sun LP, Guo AZ, Yang LG (2014) Toll-like receptor 6 gene polymorphisms increase the risk of bovine tuberculosis in Chinese Holstein cattle.Acta Histochem 116:1159-

70. Takeda K, Kaisho T, Akira S (2003) Toll-like receptors.Annu Rev Immunol 21:335-TamuraK, Stecher G, Peterson D, Filipski A, Kumar S (2013) MEGA6: molecular evolutionary genetics analysis version 6.0.Mol Biol Evol 30:2725-2729. 
71. Tao X, Huang YK, Wang C, Chen F, Yang LL, Ling L et al. (2020) Recent developments in molecular docking technology applied in food science: a review. IntJFood SciTech 55:33-

72. Tirumurugaan KG, Dhanasekaran S, Raj GD, Raja A, Kumanan K, Ramaswamy V (2010) Differential expression of toll-like receptor mRNA in selected tissues of goat (Capra hircus).Vet Immunol Immunop133:296-

73. Turin L, Riva F (2008) Toll-like receptor family in domestic animal species.CritRev Immunol28:513-

74. Vahanan BM, Raj GD, Pawar RMC, Gopinath VP, Raja A, Thangavelu A (2008) Expression profile of toll like receptors in a range of water buffalo tissues (Bubalus bubalis).Vet Immunol Immunop126:149-

75. Verma G, Ramneek R, Mukhopadhyay CS, Sethi RS (2016) Acute ethion exposure alters expression of TLR 9 in lungs of mice. Indian JVetAnat28:40-

76. Vieux EF, Barrick D (2011) Deletion of internal structured repeats increases the stability of a leucinerich repeat protein, YopM.Biophys Chem 159:152-

77. von HeijneG (1990) The signal peptide.J Membrane Biol 115:195-

78. Wanapat M, Chanthakhoun V (2015) Buffalo production for emerging market as a potential animal protein source for global population.Buffalo Bull 34:169-

79. Waterhouse A, Bertoni M, Bienert S, Studer G, Tauriello G, Gumienny R et al. (2018) SWISS-MODEL: homology modelling of protein structures and complexes.Nucleic Acids Res 46:296-

80. Werling D, Coffey TJ (2007) Pattern recognition receptors in companion and farm animals-The key to unlocking the door to animal disease? The VetJ 174:240-

81. Werling D, Piercy J, Coffey TJ (2006) Expression of TOLL-like receptors (TLR) by bovine antigenpresenting cells-Potential role in pathogen discrimination? Vet Immunol Immunop112:2-

82. Yachdav G, Kloppmann E, Kajan L, Hecht M, Goldberg T, Hamp T et al. (2014)PredictProtein-an open resource for online prediction of protein structural and functional features.Nucleic Acids Res42:337-

83. Yamamoto M, Takeda K, Akira S (2004) TIR domain-containing adaptors define the specificity of TLR signaling.Mol Immunol 40:861-868.

84. Yilmaz A, Shen SX, Adelson DL, Xavier S, Zhu JJ (2005) Identification and sequence analysis of chicken Toll-like receptors.Immunogenetics 56:743-

85. Yindee M, Vlamings BH, Wajjwalku W, Techakumphu M, Lohachit C, Sirivaidyapong S et al. (2010) Ychromosomal variation confirms independent domestications of swamp and river buffalo.Anim Genet 41:433-

86. Zhang CX, Wu WC, Zou LS, Shi RX (2000) Science and technology in Chinese buffaloes, 1 stedn. Guangxi Science and Technology Press: Nanning (in Chinese).

\section{Figures}


a

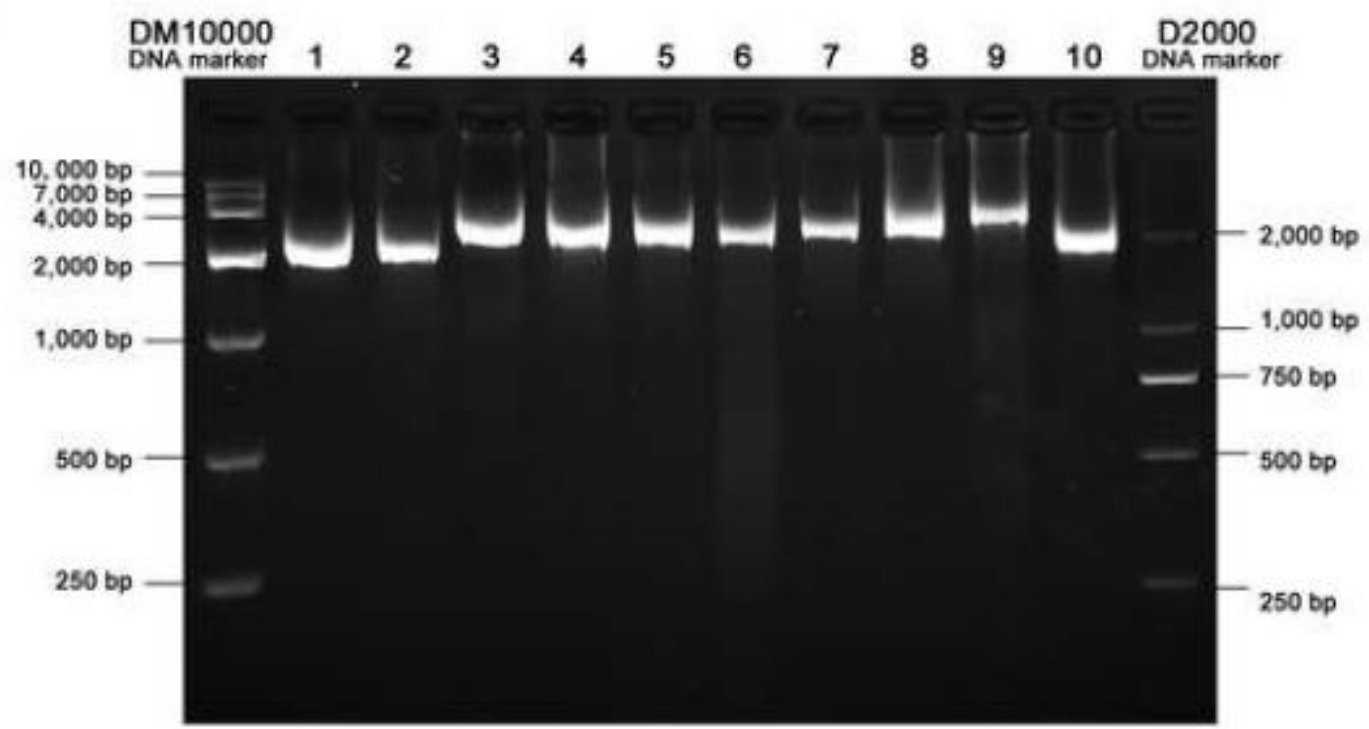

b

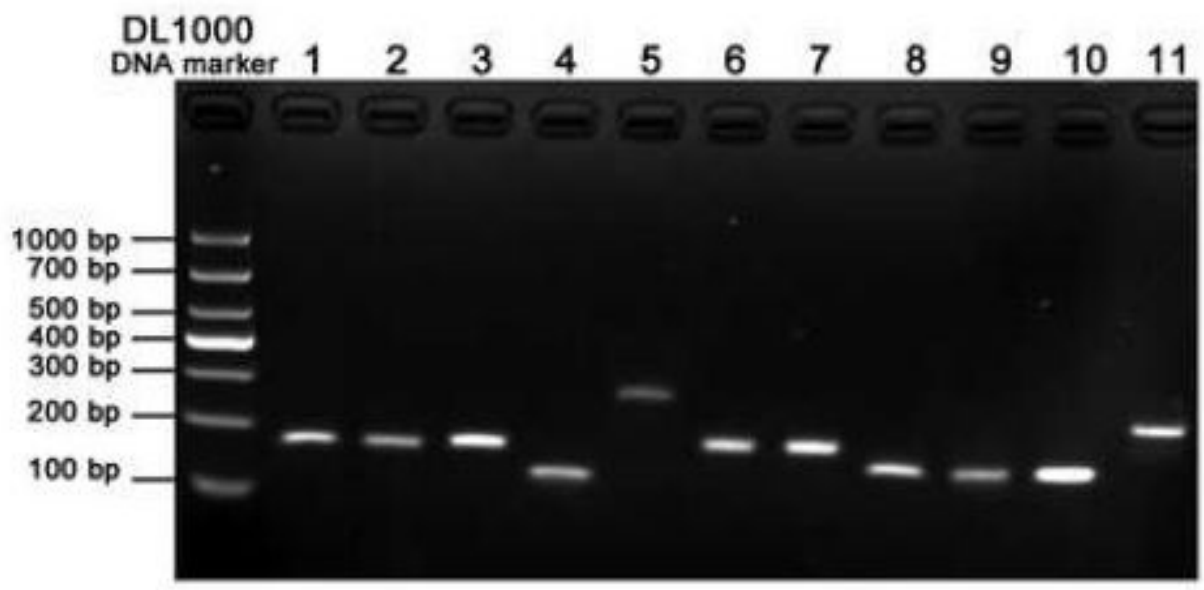

\section{Figure 1}

Results of the electrophoresis analysis. (a) Photograph of the agarose gel electrophoretic patterns of PCR products of GX buffalo TLRs 1-10 full-length genes. (b) RT-qPCR products of specific fragments of bubaline TLRs 1-10 genes and the reference house-holding gene GAPDH. 

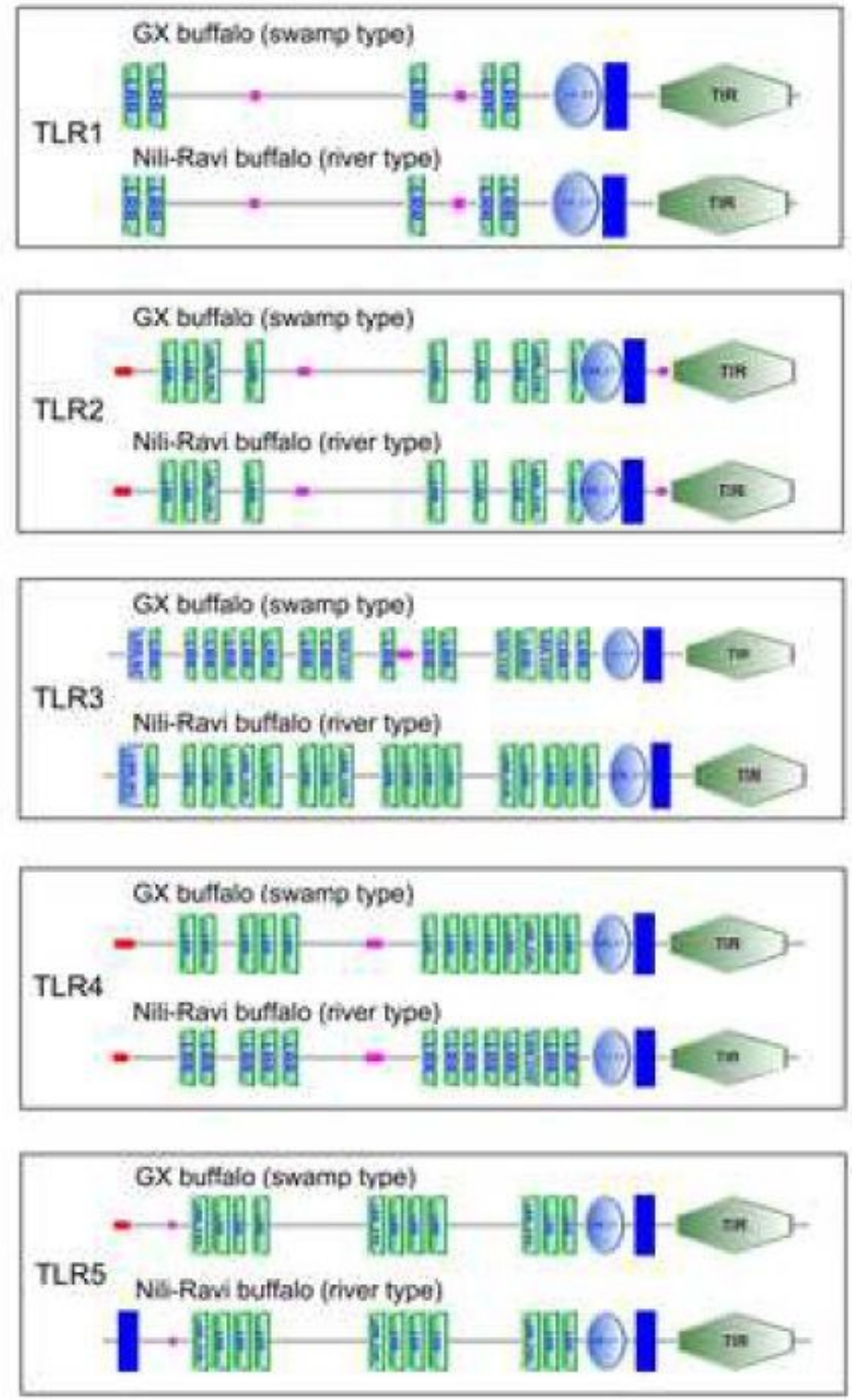

- Signal peptide = Low complexity region

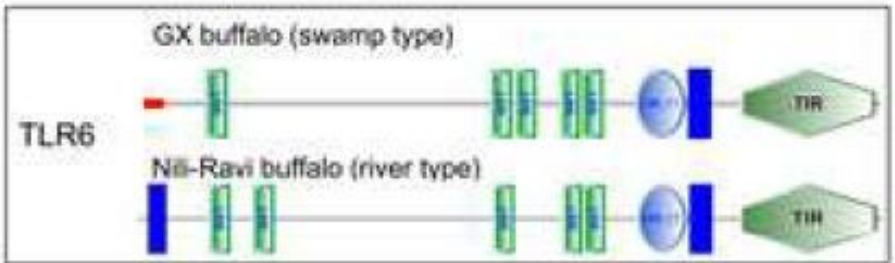

GX buffalo (swamp type)

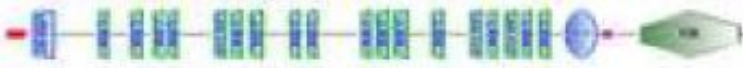

TLR7

Nis-Rawi buffalo (river type)

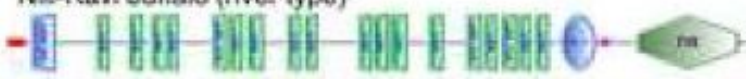
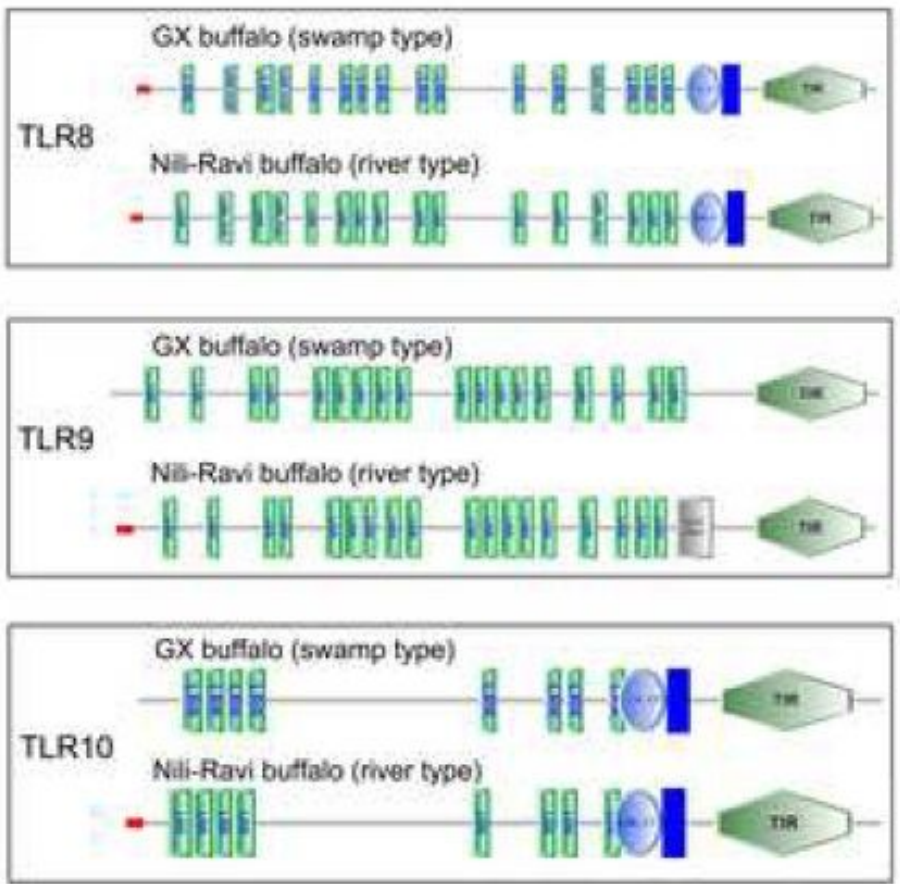

Transmembrane region

\section{Figure 2}

Predicted functional domains in TLRs 1-10 proteins of GX buffaloes (swamp-type) compared to NR buffaloes (river-type) as revealed by the genomic mode of SMART tool. 

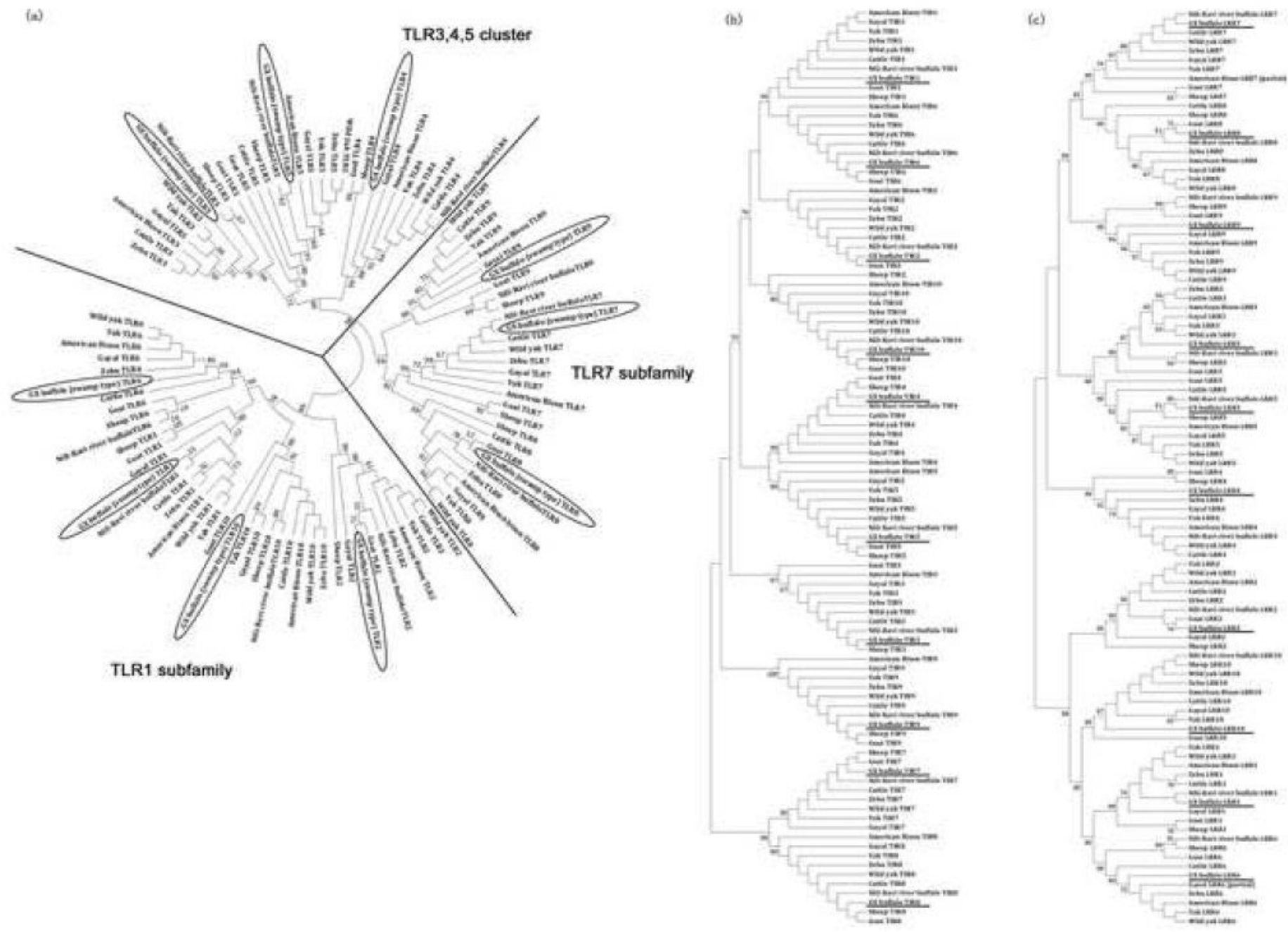

Figure 3

Phylogenetic Neighbor-Joining (NJ) trees of ruminant (a) TLRs 1-10 genes, (b) TIRs and (c) LRRs of TLRs based on amino acid sequences of TLRs 1-10 from GX buffaloes, Nili-Ravi river buffaloes, cattle, American bison, zebu, yak, wild yak, gayal, goat, and sheep. The bootstrap values are indicated at the nodes and only those bootstrap values $>50 \%$ are shown. The sequences obtained from the GX buffaloes are enclosed in ovals ( $a$ ) or underlined ( $b$ and $c$ ). 


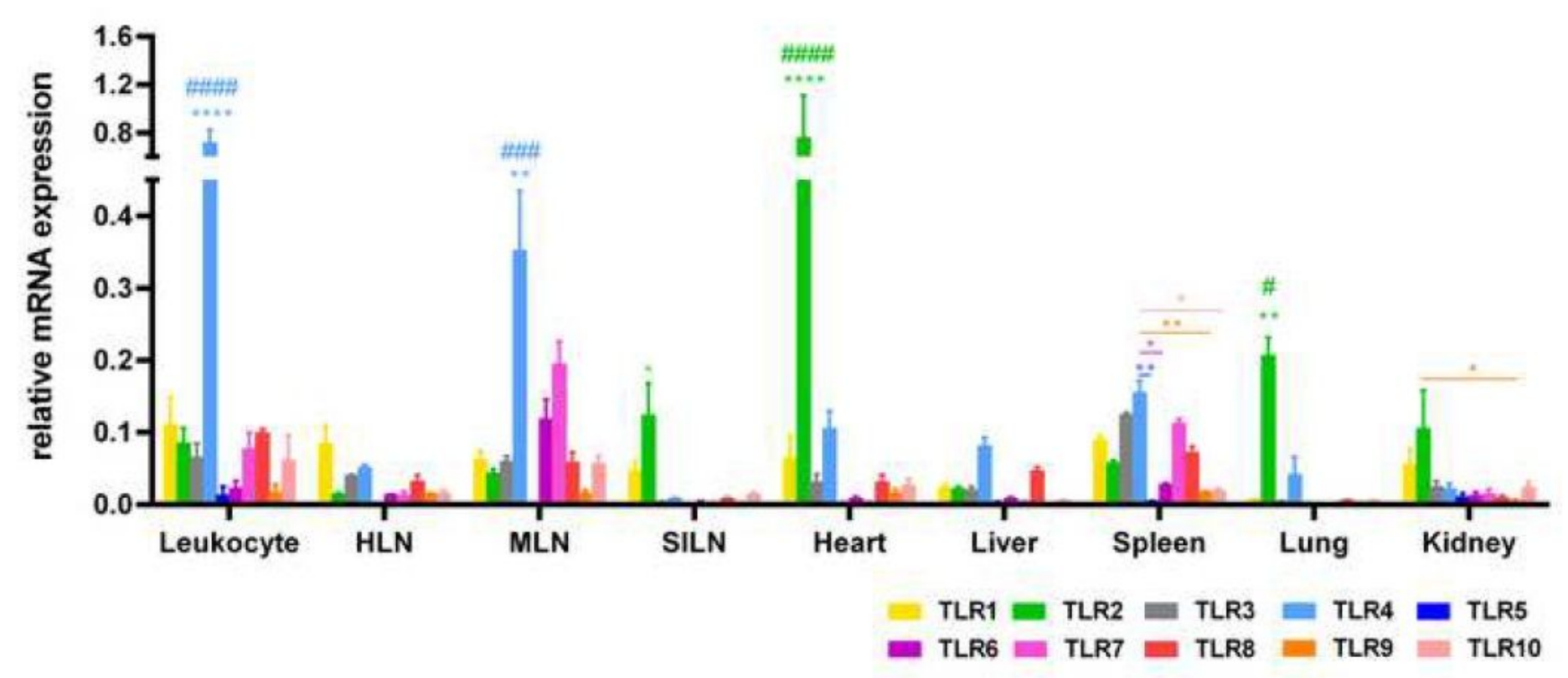

\section{Figure 4}

The comparative mRNA expression profiles of TLRs 1-10 in blood leukocytes, hepatic lymph node (HLN), mesenteric lymph node (MLN), superficial inguinal lymph node (SILN), heart, liver, spleen, lung, and kidney in GX swamp buffaloes. Data represent the mean \pm standard error from at least three independent experiments. Statistical significance between levels of expression of TLRs within the same tissue and across all tissues are indicated by * and \# symbols, respectively. (\#, *, p $<0.05$; \#\#, **, $p<0.01$ or \#\#\#\#, $\star * \star \star, p<0.0001)$. TLR4 expression in leukocytes $(p<0.0001)$ and MLN $(p<0.01)$ was significantly higher than any other TLR in the same cells and tissues, respectively. TLR4 expression in spleen was significantly higher than TLR5 $(p<0.01)$, TLR6 $(p<0.05)$, TLR9 $(p<0.01)$, and TLR10 $(p<0.05)$. TLR2 expression in SILN $(p<0.05)$, heart $(p<0.0001)$, lung $(p<0.01)$, and kidney $(p<0.05)$ was significantly higher than any other TLR in the same group, except TLR1 and TLR10 in the kidney. Across all examined samples, the highest expression of TLR4 was observed in leukocytes $(p<0.0001)$, followed by MLN $(p<$ $0.01)$ and the highest expression of TLR2 was observed in heart $(p<0.0001)$ and lung $(p<0.01)$.

\section{Supplementary Files}

This is a list of supplementary files associated with this preprint. Click to download.

- SupplementaryFigures.pdf

- TableS1.XLSX

- TableS2.XLSX

- TableS3.XLSX

- TableS4.XLSX 
- ARRIVEGuidelinesChecklist.docx

Page 33/33 